\title{
Article
}

\section{An update on the mineral-like Sr-containing transition metal arsenates}

\author{
Tamara Đorđević1* (1) and Ljiljana Karanović ${ }^{2}$ \\ ${ }^{1}$ Institut für Mineralogie und Kristallographie, Universität Wien, Althanstr. 14, A-1090 Wien, Austria; and ${ }^{2}$ Laboratory of Crystallography, Faculty of Mining and \\ Geology, Đušina 7, 11000 Belgrade, Serbia.
}

\begin{abstract}
We report on the crystal structures of three novel synthetic $\mathrm{Sr} M$-arsenates $\left(M=\mathrm{Ni}\right.$ and $\left.\mathrm{Fe}^{3+}\right)$, isostructural or structurally related to the minerals from tsumcorite, carminite and brackebuschite groups. They were synthesised under mild hydrothermal conditions and further characterised using single-crystal X-ray diffraction (SXRD), scanning electron microscopy with energy dispersive spectroscopy (SEMEDS) and Raman spectroscopy. SXRD and SEM-EDS yielded formulae: (I) $\mathrm{SrNi}_{2}\left(\mathrm{AsO}_{4}\right)_{2} \cdot 2 \mathrm{H}_{2} \mathrm{O},(\mathrm{II}) \mathrm{Sr}_{1.4} \mathrm{Fe}_{1.6}^{3+}(\mathrm{AsO})_{2}(\mathrm{OH})_{1.6}$ and (III) $\mathrm{SrFe}^{3+}\left(\mathrm{AsO}_{4}\right)\left(\mathrm{AsO}_{3} \mathrm{OH}\right)$. All three structures are built up of slightly distorted $\mathrm{MO}_{6}$ octahedra and AsO $\mathrm{A}_{4}$ tetrahedra that are linked by $\mathrm{Sr}^{2+}$ with different coordination geometries and hydrogen bonds. I represent a basic structure type typical for tsumcorite-group minerals (space group $\mathrm{C} 2 / \mathrm{m}$ ) while II has a new intermediate structure between carminite, $\mathrm{PbFe}_{2}^{3+}\left(\mathrm{AsO}_{4}\right)_{2}\left(\mathrm{OH}_{2}\right.$ and arsenbrackebuschite, $\mathrm{Pb}_{2} \mathrm{Fe}^{3+}\left(\mathrm{AsO}_{4}\right)_{2}(\mathrm{OH})($ s.g. $\mathrm{Pm})$. III is triclinic and adopts a new structure-type (s.g. $\left.P \overline{1}\right)$. The structure of $\mathbf{I}$ is built up of infinite linear edge-sharing $\mathrm{NiO}_{4}\left(\mathrm{OH}_{2}\right)_{2}$ octahedral chains, extending along [010] and linked by $\mathrm{AsO}_{4}$ tetrahedra, SrO 8 polyhedra and hydrogen bonds. The structure of II is characterised by the carminite-like $\mathrm{FeO}_{4}(\mathrm{OH})_{2}$ octahedral chains and Edshammar-polyhedral chains, which involves $\mathrm{SrO}_{11}$ coordination polyhedra similar to that of $\mathrm{PbO}_{11}$ in arsenbrackebuschite. Both chains in II are aligned parallel to the $b$ axis of the monoclinic unit cell and connected together by the arsenate $\mathrm{AsO}_{4}$ tetrahedra, $\mathrm{SrO}_{8}$ polyhedra and the hydrogen-bonding network. The compound III has a new type of crystal structure based on the unusual corrugated octahedral-tetrahedral-quadruple chains. These are made up of a central double-sided chain linked to two single-sided chains into a quadruple chain extended along the $a$ axis. The chains in III are built up of $\mathrm{FeO}_{6}$ octahedra and $\mathrm{AsO}_{4}$ tetrahedra further linked to each other by shared vertices. The quadruple chains are interconnected by additional $\mathrm{AsO}_{4}$ tetrahedra forming a heteropolyhedral 3D open framework. Strontium atoms are situated in the two channels. The structural connections to related minerals and inorganic compounds are discussed.
\end{abstract}

Keywords: metal arsenates, crystal structure, single-crystal X-ray diffraction, hydrothermal synthesis, Raman spectroscopy, environmentally relevant compounds, arsenic

(Received 5 February 2021; accepted 9 May 2021; Accepted Manuscript published online: 26 May 2021; Associate Editor: David Hibbs)

\section{Introduction}

Even though it is well known that arsenic is one of the most naturally abundant toxic metalloids, many crystal structures of arsenic oxosalts remain either undetermined or only poorly determined. This causes misunderstandings of their behaviour in various environmental media, such as soils, sediments and waters because it requires detailed knowledge of thermodynamic properties and, in particular, of formation conditions of arsenic phases and their respective crystal structures (O'Day, 2006; Drahota and Filippi, 2009). Furthermore, the crystal chemistry of transition-metal arsenates and phosphates reveals an interesting field of research for both mineralogists and solid-state researchers. Many natural or synthetic phosphates, arsenates and vanadates are of great interest due to their structural variability. In combination with the different oxidation states of some transition metals, there is a great variety of

*Author for correspondence: Tamara Đorđević, Email: tamara.djordjevic@univie.ac.at Cite this article: Đorđević T. and Karanović L. (2021) An update on the mineral-like Srcontaining transition metal arsenates. Mineralogical Magazine 85, 416-430. https:// doi.org/10.1180/mgm.2021.41 ternary and quaternary compounds. They can foster potential applications and original physical properties such as magnetism, heterogeneous catalysis, ion exchange, optics or thermal expansion (de Pedro et al., 2011; Đorđević et al., 2018 and references therein). In this context, the preparation, crystal structures, spectroscopic behaviour and some physical properties of numerous alkali-, alkali-earth and transition-metal arsenic oxosalts have been investigated (Đorđević and Karanović, 2018 and references therein).

In the present contribution we are reporting on the preparation, description of the crystal structures, and spectroscopic investigation of the three novel strontium arsenates, $\mathrm{I}-\mathrm{SrNi}_{2}\left(\mathrm{AsO}_{4}\right)_{2} \cdot 2 \mathrm{H}_{2} \mathrm{O}$, II- $\mathrm{Sr}_{1.4} \mathrm{Fe}_{1.6}^{3+}\left(\mathrm{AsO}_{4}\right)_{2}(\mathrm{OH})_{1.6}$ and III-SrFe ${ }^{3+}\left(\mathrm{AsO}_{4}\right)\left(\mathrm{AsO}_{3} \mathrm{OH}\right)$. Compound I, $\mathrm{SrNi}_{2}\left(\mathrm{AsO}_{4}\right)_{2} \cdot 2 \mathrm{H}_{2} \mathrm{O}$, is isostructural with the monoclinic members of the tsumcorite-group minerals and inorganic compounds (space group $C 2 / m$ with $Z=2$ ). Furthermore, it is the first compound synthesised and described in the $\mathrm{SrO}-\mathrm{NiO}-\mathrm{As}_{2} \mathrm{O}_{3} /$ $\mathrm{As}_{2} \mathrm{O}_{5}-\left(\mathrm{H}_{2} \mathrm{O}\right)$ system. Compound II, $\mathrm{Sr}_{1.4} \mathrm{Fe}_{1.6}\left(\mathrm{AsO}_{4}\right)_{2}(\mathrm{OH})_{1.6}$, has a new crystal structure, which is an intermediate between carminite- $\left(\mathrm{PbFe}_{2}^{3+}\left(\mathrm{AsO}_{4}\right)_{2}(\mathrm{OH})_{2}\right.$; Kharisun et al., 1996) and arsenbrackebuschite-type $\left(\mathrm{Pb}_{2} \mathrm{Fe}^{3+}\left(\mathrm{AsO}_{4}\right)_{2}(\mathrm{OH})\right.$; Hofmeister and Tillmanns, 1978) structures. Compound III, $\mathrm{SrFe}^{3+}\left(\mathrm{AsO}_{4}\right)$

(C) The Author(s), 2021. Published by Cambridge University Press on behalf of The Mineralogical Society of Great Britain and Ireland. This is an Open Access article, distributed under the terms of the Creative Commons Attribution licence (http://creativecommons.org/licenses/by/4.0/), which permits unrestricted re-use, distribution, and reproduction in any medium, provided the original work is properly cited. 

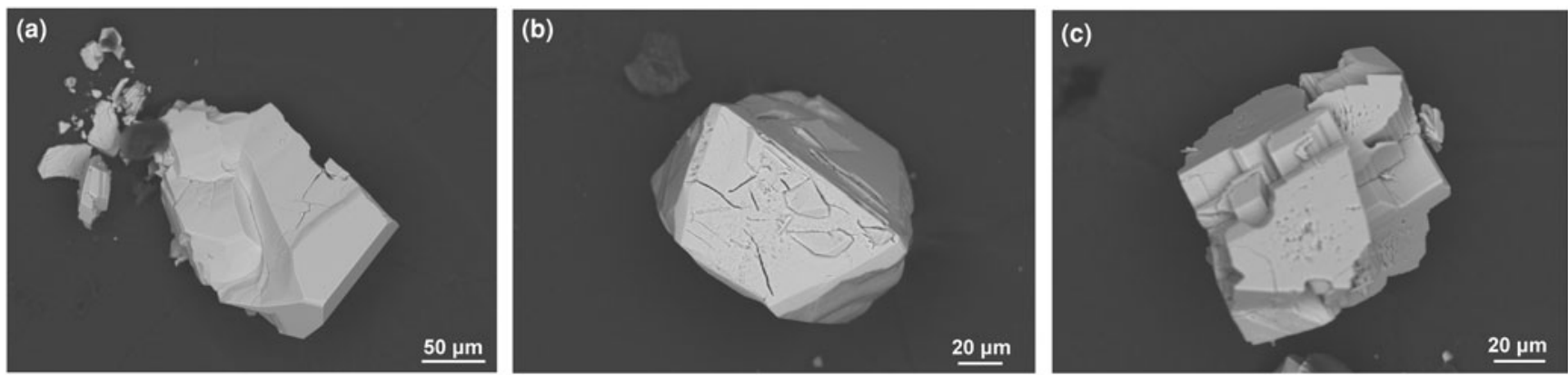

Fig. 1. Back-scattered electron images of the (a) glass-like crystal of I, (b) idiomorphic crystal of II and (c) idiomorphic crystal of III.

$\left(\mathrm{AsO}_{3} \mathrm{OH}\right)$, adopts a novel structure type that is characterised by the unique octahedral-tetrahedral-quadruple $\left[\mathrm{Fe}\left(\mathrm{AsO}_{4}\right)\right]_{n}$ infinite chains, which are composed of one central double- and two peripheral single-chains extended along the $a$ axis. Both II and III are the first compounds synthesised in the $\mathrm{SrO}-\mathrm{Fe}_{2} \mathrm{O}_{3}-\mathrm{As}_{2} \mathrm{O}_{3} /$ $\mathrm{As}_{2} \mathrm{O}_{5}-\left(\mathrm{H}_{2} \mathrm{O}\right)$ system.

All three $\mathrm{Sr} M$-arsenates adopt mixed tetrahedral-octahedral framework structures with different chains as the fundamental structural building units. The crystal-chemical features of these arsenates, their hydrogen-bonding schemes and their topological relation to the structurally-related minerals and inorganic compounds are discussed.

\section{Experimental}

\section{Preparation of the single crystals}

Compounds I-III were synthesised using low-temperature hydrothermal methods. The following reagents were used in stoichiometric quantities: $\mathrm{Sr}\left(\mathrm{NO}_{3}\right)_{2}$ (Sigma-Aldrich, 243426, $500 \mathrm{~g}$ ), $\mathrm{As}_{2} \mathrm{O}_{5}$ (Alfa Products 87687, >99.9\%), $\mathrm{Ni}(\mathrm{OH})_{2}$ (Sigma-Aldrich, S58362-518, $250 \mathrm{~g}$ ) and $\mathrm{FeCl}_{2} \cdot 4 \mathrm{H}_{2} \mathrm{O}$ (Fluka 44939, $250 \mathrm{~g}$ ).

The mixtures were transferred into polytetrafluoroethylene vessels and filled with distilled water to $80 \%$ of their inner volume. The starting mixtures had $\mathrm{pH}$ values of 3 for I and 2 for II and III. Subsequently, the mixtures were enclosed in stainless steel autoclaves and heated under autogenous pressure under the following heating and cooling conditions: the mixtures were heated from room temperature to $220^{\circ} \mathrm{C}(4 \mathrm{~h})$, held at that temperature for $48 \mathrm{~h}$, and cooled to room temperature (96 h). After cooling the $\mathrm{pH}$ values were measured as 3 for I, and 1 for II and III. The reaction products were filtered and washed several times using distilled water.

Compound I crystallised as a light green glassy-like fragment (Fig. 1) up to $0.15 \mathrm{~mm}$ long (yield ca. 60\%) accompanied by green needles of $\mathrm{SrNiAs}_{2} \mathrm{O}_{7}$ (unpublished work) (yield ca. 40\%). II crystallised as ruby red octahedra (yield ca. 20\%) up to $120 \mu \mathrm{m}$ long together with the colourless prisms of III, up to $0.2 \mathrm{~mm}$ long (yield ca. 80\%) (Fig. 1).

\section{Single-crystal $X$-ray diffraction}

The intensity data for I and III were collected on a Nonius Kappa CCD single-crystal four-circle diffractometer $(\mathrm{MoK} \alpha$ radiation, graphite monochromator), equipped with a $300 \mathrm{~nm}$ diameter capillary-optics collimator. The unit-cell parameters were determined with HKL SCALEPACK (Nonius, 2005-2007). A complete sphere of reciprocal space ( $\varphi$ and $\omega$ scans) was measured. The intensity data were processed with the Nonius program suite
DENZO-SMN (Nonius, 2005-2007) and corrected for absorption by the multi-scan method (Otwinowski et al., 2003). A singlecrystal of II was studied on a STOE StadiVari diffractometer with open Eulerian cradle, dual-beam source (sealed-tube and microfocus source) and Dectris PILATUS 300K pixel detector. Data collection for II was performed with X-AREA (Stoe, 2013), cell refinement was done using $X$-AREA (Stoe, 2013) and data reduction was performed with $X$-RED (Stoe, 2013). Single-crystal X-ray diffraction data were collected at ambient conditions, integrated and corrected for Lorentz and polarisation factors and absorption by scaling of partial multi-scans. The structures of I, II and III were solved by direct methods using SHELXT (Sheldrick, 2015a) and WinGX (Farrugia, 2012). The coordinates and the anisotropic displacement parameters for all non-hydrogen atoms were refined by full-matrix least-squares methods based on $F^{2}$ values by SHELXL (Sheldrick, 2015b).

For I anisotropic displacement parameters were allowed to vary for all atoms, except the hydrogen atoms. Hydrogen atoms from water molecules were located in the difference-Fourier map and refined using a riding model where $U_{\text {iso }}(\mathrm{H})=$ $1.5 U_{\text {eq }}(\mathrm{O})$ and with DFIX distance restraints for $\mathrm{O}-\mathrm{H}=0.85 \AA$ and $\mathrm{H} \cdots \mathrm{H}=1.37 \AA$.

For II the initially determined orthorhombic unit cell typical for the carminite structure type $[a=16.500(3), b=7.5457(15)$, $c=12.227(2) \AA, V=1522.4(5) \AA^{3}$ and $Z=8$ ] gave high values for $R$-factors and weighting scheme parameters. The electron density observed was higher than desired at two of the $\mathrm{O}$ atom positions from the $\mathrm{OH}$ groups (O6 and O7), but lower at the Fe sites. Using the known model of carminite, the residual electron density could not explain such high values. Therefore, a new model was developed in space group $P 1$, with the same lattice parameters. An additional symmetry check indicated that the smaller monoclinic cell $[a=9.0719(15), b=12.227(2), c=7.5457(15) \AA, b=114.575(6)$, $V=761.2(2) \AA^{3}$ and $\left.Z=4\right]$ and the $P m$ space group is more appropriate and the unit cell was transformed using the matrix

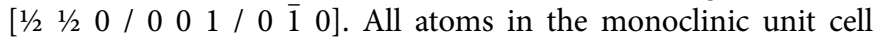
are situated in general $2 c$ positions excluding Sr21, Sr22, As11As14, O21-O24, O31-O34 and mixed sites Sr61/O61-Sr64/ O64, which are in special positions $1 a$ and $1 b$ on the mirror planes (site symmetry $m$ ) at $y=0$ and $y=1 / 2$, respectively. The structure was refined as an inversion twin. The obtained Flack parameter $x=0.570(18)$ indicate equivolume inversion twins. The transformation to monoclinic symmetry gave more than satisfactory results. The final difference-Fourier map showed no unusual features or spurious peaks around the refined positions of the atoms. The highest peak $\left(\Delta \rho_{\max }=0.65 e^{-} \AA^{-3}\right)$ in the map was found $0.80 \AA$ from $\mathrm{O} 11$. 
Table 1. Crystal data, data collection and refinement details for I-III.

\begin{tabular}{|c|c|c|c|}
\hline & I & II & III \\
\hline \multicolumn{4}{|l|}{ Crystal data } \\
\hline Chemical formula & $\mathrm{As}_{2} \mathrm{H}_{4} \mathrm{Ni}_{2} \mathrm{O}_{10} \mathrm{Sr}$ & $\mathrm{As}_{2} \mathrm{H}_{1.60} \mathrm{Fe}_{1.60} \mathrm{O}_{9.60} \mathrm{Sr}_{1.40}$ & $\mathrm{As}_{2} \mathrm{HFeO}_{8} \mathrm{Sr}$ \\
\hline$M_{\mathrm{r}}$ & 518.91 & 517.08 & 422.32 \\
\hline Crystal system, space group & Monoclinic, $\mathrm{C} 2 / \mathrm{m}$ & Monoclinic, $P m$ & Triclinic, $P \overline{1}$ \\
\hline Temperature (K) & 298 & 295 & 298 \\
\hline$a, b, c(\AA)$ & $9.173(3), 6.2025(12), 7.562(3)$ & $9.0719(15), 12.227(2), 7.5457(15)$ & $6.6379(13), 9.6849(19), 12.666(3)$ \\
\hline$\alpha, \beta, \gamma\left({ }^{\circ}\right)$ & $90,114.41(2), 90$ & $90,114.575(6), 90$ & 108.86(3), 90.97(3), 104.49(3) \\
\hline$V\left(\AA^{3}\right)$ & $391.8(2)$ & $761.2(2)$ & $741.8(3)$ \\
\hline$z$ & 2 & 4 & 4 \\
\hline Radiation type & MoK $\alpha, \lambda=0.71073 \AA$ & MoK $\alpha, \lambda=0.71073 \AA$ & MoK $\alpha, \lambda=0.71073 \AA$ \\
\hline$\mu\left(\mathrm{mm}^{-1}\right)$ & 19.97 & 21.45 & 18.01 \\
\hline Crystal size (mm) & $0.03 \times 0.02 \times 0.01$ & $0.03 \times 0.02 \times 0.02$ & $0.02 \times 0.02 \times 0.03$ \\
\hline \multicolumn{4}{|l|}{ Data collection } \\
\hline Diffractometer & Nonius Kappa CCD & STOE StadiVari diffractometer & Nonius Kappa CCD \\
\hline Absorption correction & Multi-scan & Multi-scan & Multi-scan \\
\hline $\begin{array}{l}\text { No. of measured, independent } \\
\text { and observed }[I>2 \sigma(I)] \\
\text { reflections }\end{array}$ & $1116,606,536$ & $18131,4785,4001$ & 5166, 2590, 2042 \\
\hline$\theta_{\max }, \theta_{\min }\left({ }^{\circ}\right)$ & $\begin{array}{l}29.5,4.1 \\
h=-12 \rightarrow 12, k=-8 \rightarrow 8, l=-10 \rightarrow 10\end{array}$ & $\begin{array}{l}30.5,1.7 \\
h=-12 \rightarrow 12, k=-17 \rightarrow 17, l=-10 \rightarrow 10\end{array}$ & $\begin{array}{l}25.0,2.4 \\
h=-7 \rightarrow 7, k=-11 \rightarrow 11, l=-15 \rightarrow 15\end{array}$ \\
\hline$R_{\text {int }}$ & 0.018 & 0.034 & 0.048 \\
\hline$(\sin \sigma / \lambda)_{\max }\left(\AA^{-1}\right)$ & 0.694 & 0.713 & 0.595 \\
\hline \multicolumn{4}{|l|}{ Refinement on $F^{2}$} \\
\hline$R\left[F^{2}>2 \sigma\left(F^{2}\right)\right], w R\left(F^{2}\right), S$ & $0.028,0.060,1.18$ & $0.028,0.060,1.05$ & $0.062,0.141,1.10$ \\
\hline No. of reflections & 606 & 4785 & 2590 \\
\hline No. of refined parameters & 48 & 315 & 254 \\
\hline No. of restraints & 2 & 18 & 1 \\
\hline Hydrogen site location & Difference-Fourier map & Inferred from neighbouring sites & Inferred from neighbouring sites \\
\hline $\mathrm{H}$-atom treatment & $\begin{array}{l}\mathrm{H} \text { atoms refined using DFIX } \\
\text { distance restraints with } \mathrm{O}-\mathrm{H}= \\
0.85 \AA \text { and } U_{\text {iso }}(\mathrm{H})=1.5 U_{\text {eq }}(\mathrm{O})\end{array}$ & $\begin{array}{l}\mathrm{H} \text { atoms placed in geometrically calculated } \\
\text { positions and refined using DFIX distance } \\
\text { restraints with } \mathrm{O}-\mathrm{H}=0.85 \AA \text { and } U_{\text {iso }}(\mathrm{H})= \\
1.5 U_{\text {eq }}(\mathrm{O})\end{array}$ & $\begin{array}{l}\mathrm{H} \text { atoms placed in geometrically calculated } \\
\text { positions and refined using the riding } \\
\text { model (AFIX 83) with } \mathrm{O}-\mathrm{H}=0.82 \AA \text { and } \\
U_{\text {iso }}(\mathrm{H})=1.5 U_{\text {eq }}(\mathrm{O})\end{array}$ \\
\hline Weighting & $\begin{array}{l}w=1 /\left[\sigma^{2}\left(F_{\mathrm{o}}^{2}\right)+(0.0186 P)^{2}+3.637 P\right] \\
\quad \text { where } P=\left(F_{\mathrm{o}}^{2}+2 F_{\mathrm{c}}^{2}\right) / 3\end{array}$ & $\begin{array}{l}w=1 /\left[\sigma^{2}\left(F_{\mathrm{o}}^{2}\right)+(0.0178 P)^{2}+1.8268 P\right] \\
\quad \text { where } P=\left(F_{\mathrm{o}}^{2}+2 F_{\mathrm{c}}^{2}\right) / 3\end{array}$ & $\begin{array}{l}w=1 /\left[\sigma^{2}\left(F_{\mathrm{o}}^{2}\right)+(0.0388 P)^{2}+25.0224 P\right] \text { where } \\
\quad P=\left(F_{\mathrm{o}}^{2}+2 F_{\mathrm{c}}^{2}\right) / 3\end{array}$ \\
\hline$\Delta \rho_{\max }, \Delta \rho_{\min }\left(e^{-} \AA^{-3}\right)$ & $1.05,-0.88$ & $0.65,-1.01$ & $1.52,-1.24$ \\
\hline Absolute structure & & Refined as an inversion twin & - \\
\hline $\begin{array}{l}\text { Absolute structure } \\
\text { parameter, } x\end{array}$ & - & $0.569(18)$ & - \\
\hline Extinction coefficient, $k$ & $0.0017(5)^{\$}$ & & \\
\hline
\end{tabular}

In order to find out how many octahedral vacancies are present, it was necessary to refine the site occupancies of four iron atoms, Fe11-Fe14, in the unit cell. The refinement of iron site occupancies shows that the Fe11 and Fe12 sites are more iron deficient than Fe13 and Fe14, which are almost fully occupied (63 and 97\%, respectively). This explains the observed lower electron density at the iron position in the initially determined orthorhombic unit cell. Therefore, a simple constraint using free variables was applied: the same site occupancy was refined for Fe11 and Fe12 atoms and oxygens O61, O62 and O71 from hydroxyl groups bonding with them only, as their site occupancy factors (s.o.f.) should be equal. Similarly, the s.o.f. of oxygens O63, O64 and $\mathrm{O} 72$ from another hydroxyl groups should be equal to the s.o.f. of Fe13 and Fe14. The refined cation occupancies were $0.627(2)$ and $0.968(2)$ for the first F11-O61-Fe11-O71-Fe12O62-Fe12-O71-Fe11 and second F13-O63-Fe13-O72-Fe14O64-Fe14-O72-Fe13 array, respectively. Conclusively, oxygen sites (O61, O62 and O71) and (O63, O64 and O72) in the first and second array are occupied by oxygen atoms from $\mathrm{OH}$ groups in approximately 63 and $97 \%$ of the unit cells, respectively. In the remaining 37 and $3 \%$, they are occupied by 11 -coordinated strontium atoms (Sr61, Sr62 and Sr71) and (Sr63, Sr64 and Sr72), respectively, forming six mixed $\mathrm{Sr} / \mathrm{O}$ sites. Because strontium has more electrons than oxygen, the presence of the Sr atoms, even in very small quantities, make the electron density at oxygen sites greater than expected for oxygen atoms and explains the higher electron density at positions $\mathrm{O} 6$ and $\mathrm{O} 7$ in the initially determined orthorhombic unit cell. The atomic coordinates and atomic displacement parameters of the $\mathrm{Sr}$ and corresponding $\mathrm{O}$ atoms in mixed $\mathrm{Sr} / \mathrm{O}$ sites were refined as identical.

In the latter cycles of refinement the presence of disordered Sr71 atoms was found, resulting in the appearance of two additional partly occupied Sr sites of very low occupancy (ca. 10\% of available sites), denoted as Sr81 and Sr82 and separated from Sr71 by a distance of only $0.728(6)$ and $0.697(5) \AA$, respectively. Similarly, the $S r 72$ position is also partly occupied and disordered, resulting in additional Sr83 and Sr84 atoms of very low occupancy (ca. $10 \%$ of available sites) at distances of $0.918(8)$ and $0.891(9) \AA$, respectively. This finding suggests a statistical disorder and movement of Sr71 and Sr72 atoms between these Sr81-S82 and Sr83Sr84 neighbouring sites, respectively. These movements are directed to the neighbouring iron-site vacancies. Hydrogen atoms of the $\mathrm{OH}$ groups (OH61, OH62, OH63, OH64, OH71 and $\mathrm{OH} 72)$ were placed in geometrically calculated positions and refined using a riding model where $U_{\text {iso }}(\mathrm{H})=1.5 U_{\text {eq }}(\mathrm{O})$ and DFIX distance restraints for $\mathrm{O}-\mathrm{H}=0.85 \AA$ and $\mathrm{H} \cdots A=1.95 \AA$. 
Table 2. Fractional atomic coordinates and isotropic or equivalent isotropic displacement parameters $\left(\AA^{2}\right)$ for $\mathbf{I}$.

\begin{tabular}{lllll}
\hline & \multicolumn{1}{c}{$x$} & $y$ & \multicolumn{1}{c}{$z$} & \multicolumn{1}{c}{$U_{\text {iso }}{ }^{*} / U_{\text {eq }}$} \\
\hline Sr1 & 0 & $1 / 2$ & 0 & $0.0205(2)$ \\
As1 & $-0.41918(7)$ & $1 / 2$ & $-0.22558(9)$ & $0.01074(18)$ \\
Ni1 & $1 / 4$ & $3 / 4$ & $1 / 2$ & $0.0131(2)$ \\
O1 & $0.3267(5)$ & 1 & $0.3814(8)$ & $0.0230(11)$ \\
O2 & $0.3056(5)$ & $1 / 2$ & $0.3556(6)$ & $0.0163(9)$ \\
O3 & $-0.0310(3)$ & $0.7745(5)$ & $-0.2685(4)$ & $0.0176(6)$ \\
O4 & $-0.2835(6)$ & $1 / 2$ & $0.0045(7)$ & $0.0304(12)$ \\
H1 & $0.413(2)$ & 1 & $0.365(3)$ & $0.034^{\star}$ \\
H2 & $0.253(3)$ & 1 & $0.265(4)$ & $0.034^{\star}$ \\
\hline
\end{tabular}

For III all non-hydrogen atoms excluding Sr2, which displays an extremely high degree of positional disorder, were initially refined anisotropically. The refinement in the lowest symmetry space group $P 1$ did not provide an ordered structure. However, in space group $P 1$ two disordered $\mathrm{Sr} 2$ atoms in the unit cell appear distributed among 12 positions. Two pairs of sites were related by the pseudo-inversion centre, but the remaining eight were not. This means that $\mathrm{Sr} 2$ is distributed among at least 10 positions in $P \overline{1}$, i.e. on 10 crystallographically independent sites Sr21-Sr30 with a multiplicity of two. Because Sr21-Sr30 atoms are spatially close they were refined with equal atomic displacement parameters. Their occupancies were refined using the free variables and SUMP instruction. The refined positions showed site occupancy factors from $0.225(6)$ to $0.041(4)$. Owing to the disorder of the Sr2 site, $R$ parameters are large $\left(R\left[F^{2}>2 \sigma\left(F^{2}\right)\right]\right.$ $\left.=0.06 w R\left(F^{2}\right)=0.14\right)$. However, it can be assumed that the structure determined is correct, except possibly for details.

Hydrogen atoms from $\mathrm{OH}$ groups were placed in geometrically calculated positions and refined using the riding model with $\mathrm{O}-\mathrm{H}=0.82 \AA$ and isotropic displacement parameters $U_{\text {iso }}(\mathrm{H})$ fixed to 1.5 times the $U_{\text {eq }}(\mathrm{O})$ value of the atoms they are linked to.

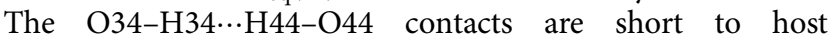
unit-occupancy $\mathrm{H}$ atoms. As a consequence, O34 and $\mathrm{O} 44$ atoms serve as both the hydrogen bond donor and acceptor, to each other, alternatively. The donor-acceptor O34...O44 distance is $2.832(17) \AA$ and the $\mathrm{H} 34 \cdots \mathrm{H} 44$ distance is $1.4827(5) \AA$. Therefore the $\mathrm{H} 34$ and $\mathrm{H} 44$ atom position occupancy is a maximum of $50 \%$, which is consistent with the charge balance.

Relevant information on crystal data, data collection and refinements are compiled in Table 1. Fractional atomic coordinates and equivalent isotropic displacement parameters for I-III are presented in Tables 2-4 and anisotropic displacement parameters for I-III are presented in Supplementary Tables S1-S3. Selected bond lengths for non- $\mathrm{H}$ atoms are listed in Table 5 and Tables S4-S6. Bond valence analysis obtained using VALIST software (Wills, 2010) are presented in Tables S7-S9. Interatomic distances and angles involving $\mathrm{H}$ atoms are given in Tables 6-8. All drawings were plotted using ATOMS (Dowty, 2000) and VESTA (Momma and Izumi, 2011). The crystallographic information files and Supplementary Tables S1-S9 have been deposited with the Principal Editor of Mineralogical Magazine and are available as Supplementary material (see below).

\section{Elemental Analysis}

Elemental analysis was performed on the hydrothermally synthesised crystals with a JEOL JSM-6610 LV scanning electron microscope (SEM) connected to an Oxford INCA Energy 350 EDX
Table 3. Fractional atomic coordinates and isotropic or equivalent isotropic displacement parameters $\left(\AA^{2}\right)$ for II.

\begin{tabular}{|c|c|c|c|c|c|}
\hline & $x$ & $y$ & $z$ & $U_{\text {iso }}{ }^{\star} / U_{\text {eq }}$ & Occ. $(<1)$ \\
\hline Sr11 & $0.9787(9)$ & $0.24995(5)$ & $0.9845(10)$ & $0.01249(12)$ & \\
\hline Sr21 & $0.4844(9)$ & 0.000000 & $0.9870(11)$ & $0.01321(17)$ & \\
\hline Sr22 & $0.4851(9)$ & 0.500000 & $0.4879(11)$ & $0.01309(17)$ & \\
\hline As11 & $0.8930(9)$ & 0.000000 & $1.1968(10)$ & $0.0069(3)$ & \\
\hline As12 & $0.8934(9)$ & 0.500000 & $0.6871(10)$ & $0.0070(3)$ & \\
\hline As13 & $1.0660(9)$ & 0.000000 & $0.7647(10)$ & $0.0075(3)$ & \\
\hline As14 & $1.0663(9)$ & 0.500000 & $1.2922(10)$ & $0.0073(3)$ & \\
\hline As21 & $1.4036(9)$ & $0.24996(8)$ & $1.1971(10)$ & $0.0063(2)$ & \\
\hline As22 & $0.5620(9)$ & $0.25007(8)$ & $0.7763(10)$ & $0.0071(2)$ & \\
\hline Fe11 & $0.7333(9)$ & $0.3668(2)$ & $1.2326(11)$ & $0.0117(5)$ & $0.628(2)$ \\
\hline Fe12 & $0.7328(9)$ & $0.1331(2)$ & $0.4921(11)$ & $0.0114(5)$ & $0.628(2)$ \\
\hline Fe13 & $1.2287(9)$ & $0.36708(12)$ & $0.7451(10)$ & $0.0081(3)$ & $0.968(2)$ \\
\hline Fe14 & $1.2285(9)$ & $0.13280(12)$ & $1.4750(10)$ & $0.0082(3)$ & $0.968(2)$ \\
\hline 061 & $0.6444(10)$ & 0.500000 & $1.0698(11)$ & $0.0233(8)$ & $0.628(2)$ \\
\hline 062 & $0.6440(10)$ & 0.000000 & $0.5658(11)$ & $0.0222(8)$ & $0.628(2)$ \\
\hline 071 & $0.8098(10)$ & $0.2501(3)$ & $1.4004(11)$ & $0.0220(8)$ & $0.628(2)$ \\
\hline Sr61 & $0.6444(10)$ & 0.500000 & $1.0698(11)$ & $0.0233(8)$ & $0.372(2)$ \\
\hline Sr62 & $0.6440(10)$ & 0.000000 & $0.5658(11)$ & $0.0222(8)$ & $0.372(2)$ \\
\hline Sr71 & $0.8098(10)$ & $0.2501(3)$ & $1.4004(11)$ & $0.0220(8)$ & $0.2975(18)$ \\
\hline Sr81 & 0.782200 & 0.199306 & 1.426899 & $0.0220(8)$ & $0.0372(2)$ \\
\hline Sr82 & 0.784300 & 0.298903 & 1.348999 & $0.0220(8)$ & $0.0372(2)$ \\
\hline 063 & $1.3140(14)$ & 0.500000 & $0.9180(16)$ & $0.018(2)$ & $0.968(2)$ \\
\hline 064 & $1.3128(14)$ & 0.000000 & $1.3858(16)$ & $0.024(2)$ & $0.968(2)$ \\
\hline 072 & $1.1365(12)$ & $0.2492(6)$ & $0.5634(16)$ & $0.0205(18)$ & $0.968(2)$ \\
\hline Sr63 & $1.3140(14)$ & 0.500000 & $0.9180(16)$ & $0.018(2)$ & $0.032(2)$ \\
\hline Sr64 & $1.3128(14)$ & 0.000000 & $1.3858(16)$ & $0.024(2)$ & $0.032(2)$ \\
\hline Sr72 & $1.1365(12)$ & $0.2492(6)$ & $0.5634(16)$ & $0.0205(18)$ & $0.0259(18)$ \\
\hline Sr83 & 1.211700 & 0.298000 & 0.643209 & $0.0205(18)$ & $0.0032(2)$ \\
\hline Sr84 & 1.213600 & 0.199903 & 0.580900 & $0.0205(18)$ & $0.0032(2)$ \\
\hline 011 & $0.9471(12)$ & $0.3882(6)$ & $1.2194(14)$ & $0.0124(16)$ & \\
\hline 012 & $0.9479(12)$ & $0.1110(6)$ & $0.7184(14)$ & $0.0115(15)$ & \\
\hline 013 & $1.0107(13)$ & $0.3873(6)$ & $0.7554(14)$ & $0.0158(17)$ & \\
\hline 014 & $1.0096(12)$ & $0.1135(6)$ & $1.2458(14)$ & $0.0150(17)$ & \\
\hline 021 & $0.7852(16)$ & 0.500000 & $0.4435(18)$ & $0.020(2)$ & \\
\hline $\mathrm{O} 22$ & $0.7875(15)$ & 0.000000 & $1.3346(17)$ & $0.016(2)$ & \\
\hline $\mathrm{O} 23$ & $1.1667(14)$ & 0.500000 & $1.5445(16)$ & $0.0074(18)$ & \\
\hline $\mathrm{O} 24$ & $1.1673(15)$ & 0.000000 & $0.6128(17)$ & $0.012(2)$ & \\
\hline 031 & $0.7609(15)$ & 0.000000 & $0.9653(16)$ & $0.020(2)$ & \\
\hline 032 & $0.7592(15)$ & 0.500000 & $0.7858(17)$ & $0.022(2)$ & \\
\hline 033 & $1.2091(15)$ & 0.000000 & $0.9916(16)$ & $0.020(2)$ & \\
\hline $\mathrm{O} 34$ & $1.2081(16)$ & 0.500000 & $1.2076(17)$ & $0.020(2)$ & \\
\hline 041 & $0.6824(13)$ & $0.2515(7)$ & $1.0143(14)$ & $0.0223(18)$ & \\
\hline 042 & $0.6819(13)$ & $0.2437(6)$ & $0.6590(14)$ & $0.0202(18)$ & \\
\hline 043 & $1.2778(12)$ & $0.2606(6)$ & $0.9602(14)$ & $0.0106(14)$ & \\
\hline 044 & $1.2778(12)$ & $0.2444(6)$ & $1.3093(14)$ & $0.0130(15)$ & \\
\hline 051 & $1.5219(12)$ & $0.3629(7)$ & $1.2646(14)$ & $0.0149(16)$ & \\
\hline 052 & $1.5224(12)$ & $0.1393(6)$ & $1.2489(14)$ & $0.0139(16)$ & \\
\hline 053 & $0.4418(12)$ & $0.3612(6)$ & $0.7191(14)$ & $0.0119(15)$ & \\
\hline 054 & $0.4415(12)$ & $0.1375(6)$ & $0.7139(14)$ & $0.0135(16)$ & \\
\hline $\mathrm{H} 61$ & $0.649(6)$ & 0.500000 & $0.959(5)$ & $0.035^{\star}$ & $0.628(2)$ \\
\hline H62 & $0.649(6)$ & 0.000000 & $0.681(2)$ & $0.033^{\star}$ & $0.628(2)$ \\
\hline H63 & $1.251(5)$ & 0.500000 & $0.976(5)$ & $0.027^{\star}$ & $0.968(2)$ \\
\hline H64 & $1.248(5)$ & 0.000000 & $1.266(2)$ & $0.036^{*}$ & $0.968(2)$ \\
\hline $\mathrm{H} 71$ & $0.9037(18)$ & $0.259(14)$ & $1.492(9)$ & $0.033^{\star}$ & $0.628(2)$ \\
\hline $\mathrm{H} 72$ & $1.0427(17)$ & $0.229(6)$ & $0.546(11)$ & $0.031^{\star}$ & $0.968(2)$ \\
\hline
\end{tabular}

analysis unit. The single crystals were mounted with conducting carbon onto Al sample holders. The sample holder was then coated with a thin layer of carbon. An accelerating voltage of $20 \mathrm{kV}$ and accumulation time of $20 \mathrm{~s}$ were used for the chemical analysis. As a qualitative measure, energy dispersive spectroscopy confirmed the presence of each reported element in the title compounds. Semi-quantitative chemical analyses gave the presence of strontium in the range of 17.0-17.4 at.\%, arsenic in the range 28.8-29.3 at\% and nickel in the range $17.8-18.9$ at\% for I, strontium in the range of $26.8-27.4$ at.\%, arsenic in the range $28.3-$ 28.4 at.\% and iron in the range $12.9-15.2$ at.\% for II and 
Table 4. Fractional atomic coordinates and isotropic or equivalent isotropic displacement parameters $\left(\AA^{2}\right)$ for III.

\begin{tabular}{|c|c|c|c|c|c|}
\hline & $x$ & $y$ & $z$ & $U_{\text {iso }}{ }^{*} / U_{\text {eq }}$ & Occ. $(<1)$ \\
\hline Sr1 & $0.3740(2)$ & $0.78866(17)$ & $0.55533(12)$ & $0.0267(4)$ & \\
\hline Sr21 & $-0.470(2)$ & $0.3620(13)$ & $0.9942(8)$ & $0.0397(15)$ & $0.210(6)$ \\
\hline Sr22 & $-0.539(2)$ & $0.4096(12)$ & $0.9889(7)$ & $0.0397(15)$ & $0.225(6)$ \\
\hline Sr23 & $-0.015(2)$ & $0.5855(15)$ & $0.7910(15)$ & $0.0397(15)$ & $0.140(6)$ \\
\hline Sr24 & $0.004(3)$ & $0.5890(19)$ & $0.7438(19)$ & $0.0397(15)$ & $0.113(6)$ \\
\hline Sr25 & $0.345(9)$ & $0.412(4)$ & $1.000(3)$ & $0.0397(15)$ & $0.054(5)$ \\
\hline Sr26 & $0.205(6)$ & $0.382(3)$ & $0.9910(19)$ & $0.0397(15)$ & $0.072(4)$ \\
\hline Sr27 & $0.363(8)$ & $0.646(4)$ & $0.978(3)$ & $0.0397(15)$ & $0.052(5)$ \\
\hline Sr28 & $0.257(7)$ & $0.687(5)$ & $0.951(3)$ & $0.0397(15)$ & $0.043(4)$ \\
\hline Sr29 & $-0.086(6)$ & $0.656(4)$ & $0.995(2)$ & $0.0397(15)$ & $0.055(4)$ \\
\hline Sr30 & $0.119(7)$ & $0.627(5)$ & $0.890(3)$ & $0.0397(15)$ & $0.041(4)$ \\
\hline As1 & $1.2429(2)$ & $0.98981(17)$ & $0.87033(11)$ & $0.0186(3)$ & \\
\hline As2 & $0.7519(2)$ & $1.18115(17)$ & $0.74450(11)$ & $0.0212(4)$ & \\
\hline As3 & $0.8813(2)$ & $0.81547(17)$ & $0.57294(11)$ & $0.0186(3)$ & \\
\hline As4 & $0.4843(2)$ & $0.51377(17)$ & $0.70512(12)$ & $0.0244(4)$ & \\
\hline Fe1 & $0.6981(3)$ & $0.8893(2)$ & $0.83659(16)$ & $0.0199(5)$ & \\
\hline $\mathrm{Fe} 2$ & $0.2395(3)$ & $1.1634(2)$ & $0.68151(15)$ & $0.0189(5)$ & \\
\hline 011 & $0.9993(14)$ & $0.8829(12)$ & $0.8546(8)$ & $0.026(2)$ & \\
\hline 012 & $1.3836(15)$ & $0.8782(12)$ & $0.7971(8)$ & $0.025(2)$ & \\
\hline 013 & $1.3401(15)$ & $1.0702(13)$ & $1.0069(8)$ & $0.031(3)$ & \\
\hline 014 & $1.2603(16)$ & $1.1421(11)$ & $0.8287(8)$ & $0.025(2)$ & \\
\hline 021 & $0.7576(17)$ & $1.1040(11)$ & $0.8434(8)$ & $0.028(2)$ & \\
\hline $\mathrm{O} 22$ & $0.9504(15)$ & $1.1796(13)$ & $0.6659(8)$ & $0.030(3)$ & \\
\hline $\mathrm{O} 23$ & $0.5313(14)$ & $1.1118(12)$ & $0.6537(7)$ & $0.022(2)$ & \\
\hline $\mathrm{O} 24$ & $0.7743(18)$ & $1.3656(12)$ & $0.8252(8)$ & $0.037(3)$ & \\
\hline $\mathrm{H} 24$ & 0.7732 & 1.4161 & 0.7844 & $0.056^{\star}$ & \\
\hline 031 & $1.1159(14)$ & $0.9371(10)$ & $0.6108(7)$ & $0.020(2)$ & \\
\hline 032 & $0.7108(16)$ & $0.8241(13)$ & $0.6695(7)$ & $0.033(3)$ & \\
\hline 033 & $0.7247(15)$ & $0.8141(12)$ & $0.4671(8)$ & $0.025(2)$ & \\
\hline 034 & $0.9536(16)$ & $0.6487(12)$ & $0.5356(10)$ & $0.036(3)$ & \\
\hline H34 & 0.8488 & 0.5767 & 0.5144 & $0.055^{\star}$ & 0.5 \\
\hline 041 & $0.6038(15)$ & $0.6643(11)$ & $0.8139(8)$ & $0.023(2)$ & \\
\hline 042 & $0.3585(17)$ & $0.3820(11)$ & $0.7581(8)$ & $0.031(3)$ & \\
\hline 043 & $0.3137(17)$ & $0.5583(13)$ & $0.6294(9)$ & $0.037(3)$ & \\
\hline 044 & $0.6633(17)$ & $0.4507(12)$ & $0.6187(8)$ & $0.034(3)$ & \\
\hline $\mathrm{H} 44$ & 0.7087 & 0.5105 & 0.5858 & $0.051^{\star}$ & 0.5 \\
\hline
\end{tabular}

strontium of 15.4 at.\%, arsenic of 34.5 at.\% and iron of 10.3 at.\% for III. The atomic proportions of constituent elements calculated from atomic \% are Sr:Ni:As = 1.2:1.3:2.0 for I, Sr:Fe:As = 1:1.9:2 for II and Sr:Fe:As = 0.9:1.1:2 for III and correspond quite well with the ratios obtained from the structural analyses.

\section{Raman spectroscopy}

To obtain further information on the anion groups, Raman spectra were acquired. Non-oriented single-crystal Raman spectra of I-III on the randomly oriented single-crystals were collected using a Horiba LabRam HR Evolution system equipped with a Si-based, Peltier-cooled CCD detector in the spectral range from 4000 to $60 \mathrm{~cm}^{-1}$. The $633 \mathrm{~nm}$ excitation line of a He-Ne laser was focused with a $50 \times$ objective on the randomly oriented single crystals of I-III. The samples spectra were acquired with a nominal exposure time of $10 \mathrm{~s}$ (confocal mode, Olympus 1800 lines $/ \mathrm{mm}, 1.5 \mu \mathrm{m}$ lateral resolutions and $\sim 3 \mu \mathrm{m}$ depth resolution).

\section{Results and discussion}

\section{Description of the crystal structures}

Crystal structure of $\mathrm{SrNi}_{2}\left(\mathrm{AsO}_{4}\right)_{2} \cdot 2 \mathrm{H}_{2} \mathrm{O}$ (I)

The basic building units in the structure of $\mathbf{I}$ are infinite linear chains of edge-sharing $\mathrm{NilO}_{4}\left(\mathrm{OH}_{2}\right)_{2}$ octahedra, extending along
Table 5. Selected bond distances $(\AA)$ in the coordination polyhedra of the compounds I-III.

\begin{tabular}{lllll}
\hline & I & II & II & III \\
\hline$M-O$ & $2.055(3)$ & $1.841(4)$ & $1.924(8)$ & $1.926(9)$ \\
$M-O$ & $2.055(3)$ & $2.000(7)$ & $1.982(6)$ & $1.990(10)$ \\
$M-O$ & $2.054(3)$ & $1.997(4)$ & $2.023(6)$ & $2.013(9)$ \\
$M-O$ & $2.054(3)$ & $2.031(7)$ & $2.025(6)$ & $2.027(9)$ \\
$M-O$ & $2.078(3)$ & $2.069(8)$ & $2.027(7)$ & $2.033(10)$ \\
$M-O$ & $2.078(3)$ & $2.187(7)$ & $2.131(5)$ & $2.107(10)$ \\
$<M-O>$ & 2.0623 & 2.0208 & 2.0187 & 2.0160 \\
$M-O$ & & & & \\
$M-O$ & & $1.847(4)$ & $1.906(8)$ & $1.948(9)$ \\
$M-O$ & & $1.995(4)$ & $2.022(7)$ & $1.964(11)$ \\
$M-O$ & & $2.006(7)$ & $2.033(7)$ & $1.975(9)$ \\
$M-O$ & & $2.026(7)$ & $2.025(6)$ & $1.976(10)$ \\
$M-O$ & & $2.027(7)$ & $2.022(7)$ & $2.022(9)$ \\
$<M-0>$ & & $2.190(7)$ & $2.123(6)$ & $2.126(9)$ \\
\hline
\end{tabular}

[010] (Fig. 2a). The coordination environment of Nil generates a tetragonal slightly elongated octahedron $\mathrm{NilO}_{4}\left(\mathrm{OH}_{2}\right)_{2}$ having two pairs of symmetry equivalent $\mathrm{O}$ atoms (two $\mathrm{O} 1$ at a distance of 2.055(3) and two O3 at a distance of 2.054(3), Table S4) and two apical O2 at a distance of 2.078(3) $\AA$. The $\mathrm{NilO}_{4}\left(\mathrm{OH}_{2}\right)_{2}$ octahedra are almost perfect with an average $\langle\mathrm{Ni1}-\mathrm{O}\rangle$ distance of $2.062 \AA$, which is in agreement with the value of $2.09 \AA$ calculated from the sum $(0.69+1.4=2.09 \AA)$ of effective ionic radii (Shannon, 1976).

Adjacent octahedral chains are linked to each other by sharing corners with $\mathrm{AsO}_{4}$ tetrahedra (Fig. 2a, b). The individual As-O bond lengths vary from $1.669(5)$ to $1.702(4) \AA$, the average $<$ As-O $>$ distance is $1.685 \AA$ which is close to the sum of the effective ionic radii of $\mathrm{As}^{+5}$ in tetrahedral coordination and $\mathrm{O}^{2-}(0.335+1.4=1.735 \AA$; Shannon, 1976). The linear octahedral chains and $\mathrm{AsO}_{4}$ tetrahedra are arranged in layers parallel to (001) (Fig. 2a, b). The topology of the layer is identical to that in natrochalcite, $\mathrm{NaCu}_{2}\left(\mathrm{SO}_{4}\right)_{2}\left(\mathrm{H}_{3} \mathrm{O}_{2}\right)$ (Krickl et al., 2007; Hawthorne et al., 2000; Hawthorne, 2014).

Between these layers are situated 8-coordinated (6+2) $\mathrm{Sr}^{2+}$ cations. The mutually isolated $\mathrm{SrO}_{8}$ coordination polyhedra can be described as a somewhat distorted orthorhombic prism or dicapped slightly elongated octahedron, where the four symmetry equivalent $\mathrm{O} 3$ oxygen atoms are located in the equatorial plane and two $\mathrm{O} 4$ are at the vertices. In addition, two opposite triangular faces are capped by two $\mathrm{O} 2$ atoms at longer distances. The SrO distances are in the range 2.573(3)-2.976(5) $\AA$ and the average value is $2.684 \AA$ (Table S4), which is in agreement with the value of $2.66 \AA$ calculated from the sum $(1.26+1.4=2.66 \AA$ ) of effective ionic radii for $\mathrm{Sr}^{2+}$ with coordination number $(\mathrm{CN})=8$ (Shannon, 1976).

The other way of describing the crystals structure of I are two kind of slabs positioned alternately along the [001] direction (Fig. 2b). The $\mathrm{SrO}_{8}$ polyhedra share two edges and four vertices with six adjacent $\mathrm{AsO}_{4}$ tetrahedra forming the first slab situated between $z$ at approximately -0.33 and 0.33 . The thickness of this slab is approximately double the thickness of the second slab which hosts $\mathrm{NilO}_{4}\left(\mathrm{OH}_{2}\right)_{2}$ octahedra chains combined with intralayer hydrogen bonds. Its boundaries lie between $z$ at approximately 0.33 and 0.67 .

Bond-valence calculations (Brown and Altermatt, 1985; Brese and O'Keeffe, 1991) show that the $\mathrm{Sr}-\mathrm{O}, \mathrm{Ni}-\mathrm{O}$ and $\mathrm{As}-\mathrm{O}$ bond lengths are consistent with the presence of $\mathrm{Sr}^{2+}, \mathrm{Ni}^{2+}, \mathrm{As}^{5+}$ and 
Table 6. Hydrogen-bond geometry $\left(\AA{ }^{\circ}{ }^{\circ}\right)$ for $\mathbf{I}$.

\begin{tabular}{lcccc}
\hline$D-\mathrm{H} \cdots A$ & $D-\mathrm{H}$ & $\mathrm{H} \cdots A$ & $D \cdots A$ & $D-\mathrm{H} \cdots A$ \\
\hline $\mathrm{O} 1-\mathrm{H} 1 \cdots \mathrm{O}^{x v}$ & $0.85(2)$ & $2.36(2)$ & $2.935(10)$ & $125(1)$ \\
$\mathrm{O} 1-\mathrm{H} 1 \cdots 3^{x v i}$ & $0.85(2)$ & $2.29(1)$ & $2.909(5)$ & $130(1)$ \\
$\mathrm{O} 1-\mathrm{H} 1 \cdots 3^{\text {xvii }}$ & $0.85(2)$ & $2.29(1)$ & $2.909(5)$ & $130(1)$ \\
$\mathrm{O} 1-\mathrm{H} 2 \cdots 4^{\text {xii }}$ & $0.86(2)$ & $1.86(4)$ & $2.601(7)$ & $144(4)$ \\
\hline
\end{tabular}

Symmetry codes: (xiii) $x+1 / 2, y+1 / 2, z(x v)-x+1,-y+2,-z+1$; (xvi) $-x+1 / 2,-y+3 / 2,-z$; (xvii) $-x+1 / 2$, $y+1 / 2,-z$.

Table 7. Hydrogen-bond geometry $\left(\AA{ }^{\circ}{ }^{\circ}\right)$ for II.

\begin{tabular}{|c|c|c|c|c|}
\hline$D-\mathrm{H} \cdots A$ & $D-\mathrm{H}$ & $\mathrm{H} \cdots A$ & $D \cdots A$ & $D-\mathrm{H} \cdots A$ \\
\hline $\mathrm{O} 61-\mathrm{H} 61 \cdots \mathrm{O} 32$ & $0.85(2)$ & $1.95(2)$ & $2.745(8)$ & $155(5)$ \\
\hline $\mathrm{O} 62-\mathrm{H} 62 \cdots \mathrm{O} 31$ & $0.86(2)$ & $1.95(2)$ & $2.748(8)$ & $154(5)$ \\
\hline $\mathrm{O} 63-\mathrm{H} 63 \cdots \mathrm{O} 34$ & $0.85(2)$ & $1.95(2)$ & $2.728(10)$ & 153(5) \\
\hline $\mathrm{O} 64-\mathrm{H} 64 \cdots 033$ & $0.85(2)$ & $1.95(2)$ & $2.721(10)$ & $151(4)$ \\
\hline $\mathrm{O} 71-\mathrm{H} 71 \cdots 072^{x}$ & $0.84(2)$ & $1.95(2)$ & $2.695(5)$ & $147(3)$ \\
\hline $\mathrm{O} 72-\mathrm{H} 72 \cdots 071^{v i i}$ & $0.85(2)$ & $1.95(2)$ & $2.695(5)$ & $145(3)$ \\
\hline
\end{tabular}

Symmetry code: (vii) $x, y, z-1 ;(\mathrm{x}) x, y, z+1$.

$\mathrm{O}^{2-}\left(\Sigma v_{\mathrm{ij}}=1.886(6)\right.$ valence units (vu) for Sr1 with $\mathrm{CN}=8, \Sigma v_{\mathrm{ij}}=$ 2.106(6) vu for Ni1 with $\mathrm{CN}=6, \Sigma v_{\mathrm{ij}}=4.991$ (1) vu for As1 with $\mathrm{CN}=4$ ). If four symmetry equivalent $\mathrm{O} 4$ oxygen atoms at very long distances of 3.675(3) $\AA$ are included, the bond valence sum $\Sigma v_{\mathrm{ij}}$ for Sr1 is $1.944 \mathrm{vu}$ (Table S7). The bond valence sum for 4-coordinated $\mathrm{O} 2$, which is not included in hydrogen bonding, is close to the nominal valence of $2-\left(\sum v_{\mathrm{ij}}=1.962(2) \mathrm{vu}\right)$. Without taking into account the contribution from hydrogen atoms, the sum of the bond valences around another three $\mathrm{O}$ atoms in the structure is lower: $\Sigma v_{\mathrm{ij}}=0.72(6), 1.90(5)$ and 1.56(2) vu which contribute less than $2 \%$ each to the bond valence sum), respectively. This indicates that atoms $\mathrm{O} 1$ and $\mathrm{O} 4$ are preferentially involved in the hydrogen bonding.

The occupancy of the $M$ site with divalent $\mathrm{Ni}^{2+}$ in I causes a complete occupation of the $\mathrm{O} 1$ sites by $\mathrm{H}_{2} \mathrm{O}$ molecules and the occurrence of one interlayer and one intralayer hydrogen bond. The strong interlayer hydrogen bonds are placed across the layers between $\mathrm{O} 1$ and $\mathrm{O} 4$ (Fig. $2 \mathrm{a}-\mathrm{c}$ ). The weak intralayer hydrogen bonds extend between two symmetry equivalent $\mathrm{O} 1$ atoms belonging to two adjacent octahedral chains (Table 6). The O1-O $4^{x i i i}$ distance of 2.601(7) $\AA$ is rather short, while another donor-acceptor distance $\mathrm{O} 1-\mathrm{O} 1^{i x}$ of $2.935(10) \AA$ is in the usual range for common hydrogen bonds. The first is straight and strong, while the second is a bent and weak hydrogen bond $\left(\mathrm{O} 1-\mathrm{H} 2 \cdots \mathrm{O} 4^{x i i i}\right.$ and $\mathrm{O} 1-\mathrm{H} 1 \cdots \mathrm{O} 1^{x v}$ angles are $144(4)$ and $125(1)^{\circ}$, respectively; symmetry codes: $(\mathrm{xv})-x+1,-y+2,-z+1$; (xiii) $x+1 / 2$, $y+1 / 2, z)$.

Unlike I and its phosphate analogue $\mathrm{SrNi}_{2}\left(\mathrm{PO}_{4}\right)_{2} \cdot 2 \mathrm{H}_{2} \mathrm{O}$ (Assani et al., 2010), in the majority of tsumcorite-group members intralayer hydrogen bonds are usually much shorter and stronger than the interlayer hydrogen bonds. According to Effenberger et al. (2000) an increase in the O1-O1 distance indicates the absence of strong symmetry restricted hydrogen bonds between two symmetry equivalent $\mathrm{O} 1$ atoms. In the structure of the I hydrogen atom $\mathrm{H} 1$ is moved away from the inversion centre and therefore the intermolecular $\mathrm{O} 1-\mathrm{H} 1 \cdots \mathrm{H} 1-\mathrm{O} 1$ contacts became long enough to host unit-occupancy $\mathrm{H} 1$ atoms. As a consequence, two symmetry equivalent $\mathrm{O} 3$ atoms became suitable to act as acceptors of adjacent $\mathrm{H} 1$ (donor-acceptor distance is $2.909(5) \AA$ for $\mathrm{O} 1-\mathrm{H} 1 \cdots \mathrm{O} 3^{x v i}$ and $\mathrm{O} 1-\mathrm{H} 1 \cdots \mathrm{O} 3^{x v i i}$; symmetry
Table 8. Hydrogen-bond geometry $\left.(\AA)^{\circ}{ }^{\circ}\right)$ for III.

\begin{tabular}{|c|c|c|c|c|}
\hline$D-\mathrm{H} \cdots A$ & $D-\mathrm{H}$ & $H \cdots A$ & $D \cdots A$ & $D-\mathrm{H} \cdots A$ \\
\hline $\mathrm{O} 24-\mathrm{H} 24 \cdots 044^{\mathrm{xi}}$ & 0.82 & 2.36 & $3.114(16)$ & 153 \\
\hline 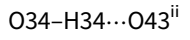 & 0.82 & 1.97 & $2.631(16)$ & 137 \\
\hline O34-H34…044 & 0.82 & 2.26 & $2.833(15)$ & 128 \\
\hline $\mathrm{O} 44-\mathrm{H} 44 \ldots 034$ & 0.82 & 2.08 & $2.833(15)$ & 152 \\
\hline $\mathrm{O} 44-\mathrm{H} 44 \cdots 043^{\mathrm{ii}}$ & 0.82 & 2.58 & $3.123(14)$ & 125 \\
\hline
\end{tabular}

Symmetry codes: (ii) $-x+1,-y+1,-z+1 ;(x i) x, y+1, z$.

codes: (xvi) $-x+1 / 2,-y+3 / 2,-z$; (xvii) $-x+1 / 2, y+1 / 2,-z$ ). These bonds are weak and bent $\left(\mathrm{O} 1-\mathrm{H} 1 \cdots \mathrm{O} 3^{x v i}\right.$ and $\mathrm{O} 1-\mathrm{H} 1 \cdots \mathrm{O} 3^{x v i i}$ angles are $\left.130(1)^{\circ}\right)$. In such a way $\mathrm{O} 1$ is involved in forming weak trifurcated hydrogen bonds $\left(\mathrm{O} 1-\mathrm{H} 1 \cdots\left(\mathrm{O}^{x v}, \mathrm{O}^{x v i}, \mathrm{O}^{x v i}\right)\right)$ that are placed between chains in one layer and strong $\mathrm{O} 1-$ $\mathrm{H} 2 \cdots \mathrm{O} 4^{x i i i}$ interlayer hydrogen bonds located between layers.

Crystal structure of $\mathrm{Sr}_{1.4} \mathrm{Fe}_{1.6}\left(\mathrm{AsO}_{4}\right)_{2}(\mathrm{OH})_{1.6}$ (II)

Compound II is only partly (ca. 80\%) isostructural with carminite, $\mathrm{Pb}^{2+} \mathrm{Fe}_{2}^{3+}\left(\mathrm{AsO}_{4}\right)_{2}(\mathrm{OH})_{2}$, which means that there are regions where the carminite-type structure is maintained in the form of octahedral $\mathrm{Fe}(\mathrm{O}, \mathrm{OH})_{6}$ chains (Fig. 3a). In contrast to carminite, the structure of II contains four partially vacant $\mathrm{Fe}$ and six mixed $\mathrm{Sr} / \mathrm{O}$ sites in which 11-coordinated $\mathrm{Sr}^{2+}$ and oxygen atoms from $\mathrm{OH}$ groups statistically share the same position. Therefore, in addition to edge-sharing octahedral $\mathrm{Fe}_{2}(\mathrm{O}, \mathrm{OH})_{10}$ dimers that build infinite octahedral chains running along [010], such as in carminite, a new type of chain is formed. These new chains (Figs $3 b, c$ ) are similar to the $\mathrm{PbO}_{11}$-chains in arsenbrackebuschite and can be described as trapezoidal facesharing Sr centred Edshammar polyhedra connected along [010].

The parallel octahedral $\mathrm{Fe}(\mathrm{O}, \mathrm{OH})_{6}$-chains and Edshammar polyhedral $\mathrm{SrO}_{11}$-chains are distributed statistically over two parallel rows in the unit cell. The octahedral $\mathrm{Fe}(\mathrm{O}, \mathrm{OH})_{6}$-chain in the first row consists of edge-shared $\mathrm{Fe} 11_{2}(\mathrm{O}, \mathrm{OH})_{10}$ and $\mathrm{Fe} 12_{2}(\mathrm{O}, \mathrm{OH})_{10}$ octahedral dimers which are linked in chains sharing corners. In the second row, the chain is formed by similar edge-shared $\mathrm{Fe} 13_{2}(\mathrm{O}, \mathrm{OH})_{10}$ and $\mathrm{Fe} 14_{2}(\mathrm{O}, \mathrm{OH})_{10}$ octahedral dimers (Fig. 3a). All octahedral dimers share an edge along mirror planes at $y=0$ and 0.5 in the first and second row, respectively. According to the refinement results, the volume occupied by the $\mathrm{Fe} 11_{2}(\mathrm{O}, \mathrm{OH})_{10}-\mathrm{Fe} 12_{2}(\mathrm{O}, \mathrm{OH})_{10}$ chain is $63 \%$ and then by the $\mathrm{Fe} 13_{2}(\mathrm{O}, \mathrm{OH})_{10}-\mathrm{Fe} 14_{2}(\mathrm{O}, \mathrm{OH})_{10}$ chain is $97 \%$. This means that the Edshammar polyhedral $\mathrm{SrO}_{11}$-chains occupy the first and second row by 37 and 3\%, respectively.

Four iron cations Fe11-Fe14, situated at general positions on the pseudoinversion centre, are coordinated by the four oxygen anions belonging to the $\mathrm{AsO}_{4}$ tetrahedra and two oxygen anions belonging to the hydroxyl groups. The $\mathrm{Fe}(\mathrm{O}, \mathrm{OH})_{6}$ dimeric octahedra are distorted showing one shorter, four typical and one longer $\mathrm{Fe}-\mathrm{O}$ bonds close to the calculated value from effective ionic radii of 6 -coordinated $\mathrm{Fe}^{3+}$ cations $(0.65+1.4=2.05 \AA$; Shannon, 1976). Oxygen from the common edge of the dimer and the oxygen from the hydroxyl group bridging two adjacent dimers in the octahedral chain form the longest and the shortest $\mathrm{Fe}-\mathrm{O}$ interatomic distances, respectively. The average $\left\langle\mathrm{Fe}^{3+}-\mathrm{O}\right\rangle$ bond distances are similar and very close to the calculated value: 2.021, 2.015, 2.019 and $2.022 \AA$ for $\mathrm{Fe} 11(\mathrm{O}, \mathrm{OH})_{6}, \mathrm{Fe} 12(\mathrm{O}, \mathrm{OH})_{6}$, $\left.\mathrm{Fe} 13(\mathrm{O}, \mathrm{OH})_{6}\right]$ and $\mathrm{Fe} 14(\mathrm{O}, \mathrm{OH})_{6}$ octahedra, respectively (Table 5).

All arsenic atoms are coordinated by four nearest oxygens, adopting a typical tetrahedral coordination. In the carminite 
(a)

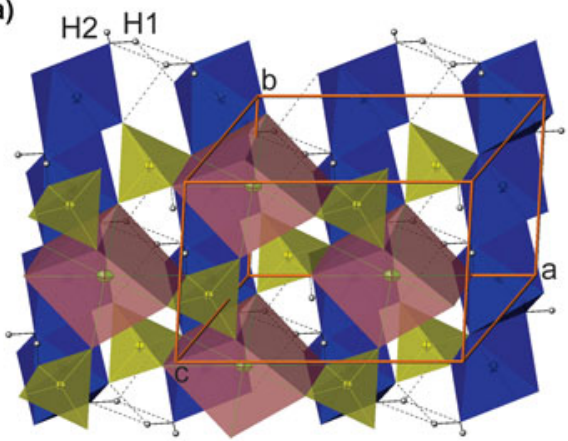

(b)

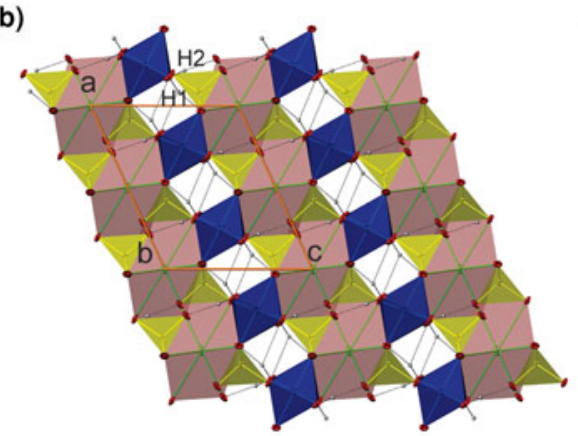

(c)

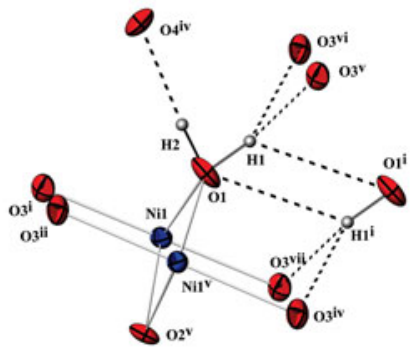

Fig. 2. (a) The edge-sharing $\mathrm{Ni}_{4}\left(\mathrm{OH}_{2}\right)_{2}$-octahedra chains (blue) extending along [010] and bonded with As $1 \mathrm{O}_{4}$-tetrahedra in a layer parallel to (001) which are linked by dicaped $\mathrm{Sr}_{1} \mathrm{O}_{8}$ octahedra (dark pink) in $\mathbf{~ ; ~ ( b ) ~ t h e ~ p r o j e c t i o n ~ o f ~ I ~ a l o n g ~ t h e ~} b$ axis showing two types of slabs parallel to (001); (c) the interlayer and intralayer hydrogen bonds in $\mathbf{I}$. $\mathbf{H}$ atoms are presented as small spheres and $\mathrm{H}$-bonds are shown as the broken lines.

(a)

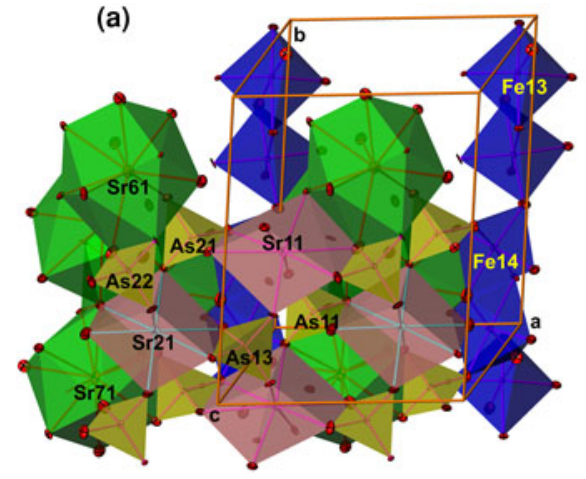

(b)

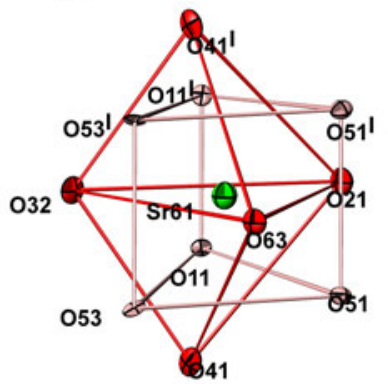

(c)

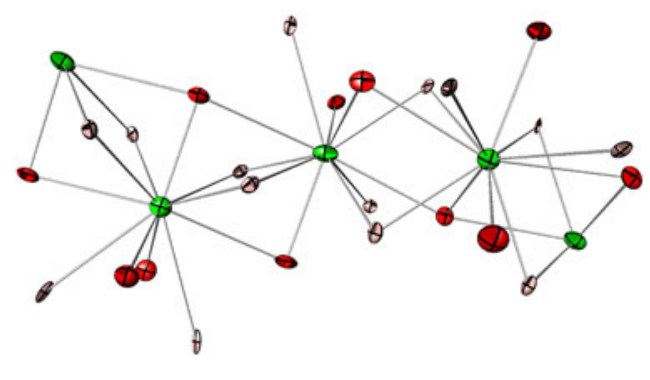

(d)

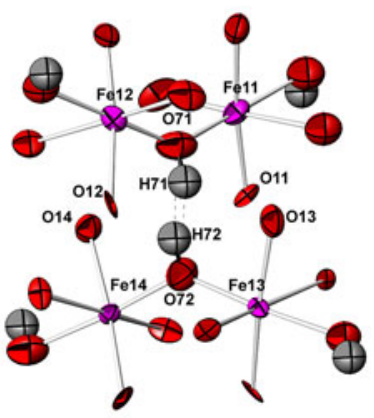

(e)

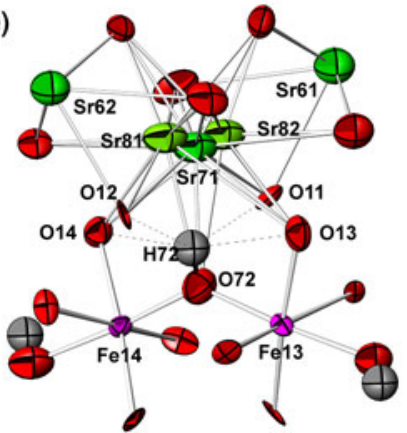

Fig. 3. (a) Polyhedral view of II showing two octahedral $\mathrm{Fe}(\mathrm{O}, \mathrm{OH})_{6}$-chains and two Edshammar polyhedral $\mathrm{SrO}_{11}$-chains arranged parallel to the $b$ axis; (b) Edshammar polyhedron $\mathrm{Sr}_{10} \mathrm{O}_{11}$ with the atom labelling scheme; (c) the infinite Edshammar polyhedral $\mathrm{SrO}_{11}$-chains. Sr81 and $\mathrm{Sr}^{-} 2$ atoms are omitted for clarity; (d) hydrogen bonds between 072 and 071 in the carminite-like part of structure; and (e) hydrogen bonds between 072 and two oxygens, 012 and 013 , in the arsenbrackebuschite-like part of the structure. The environment of Sr71 shows the positions and atom-displacement parameters of Sr81 and Sr82 atoms (occupying ca. $10 \%$ of available sites) at a distance of only $0.724(6)$ and $0.697(5) \AA$ from Sr71, respectively.

part of structure four arsenic atoms As11-As14 share only three oxygens with the $\mathrm{Fe}(\mathrm{O}, \mathrm{OH})_{6}$ octahedra, while the forth oxygen is bonded, besides As, only to 8-coordinated Sr. The other two arsenic atoms As21 and As22 are linked through all four vertices to As, $\mathrm{Sr}$ and to the adjacent octahedral chains. In the less pronounced arsenbrackebuschite part of structure only two oxygens from $\mathrm{AsO}_{4}$ tetrahedra are shared with $\mathrm{Fe}(\mathrm{O}, \mathrm{OH})_{6}$ octahedra. Another two are linked to the 8 and 11-coordinated $\mathrm{Sr}^{2+}$. In comparison to the other As-O bonds in tetrahedra, which vary from 1.657(9) to 1.692(8) A, only As13-O24 and As14-O23 bond distances are slightly elongated (1.741(9) and 1.736(8) $\AA$ ), indicating a disorder and the possible involvement in hydrogen bonding.
The average $<$ As- $\mathrm{O}>$ bond distances $(1.680,1.682,1.688,1.692$, 1.681 and $1.671 \AA$ for $\langle$ As11-O $\rangle,\langle$ As14-O $\rangle,\langle$ As21-O $\rangle$ and $<$ As22-O $>$, respectively) are in accordance, or slightly shorter, than the sum of the effective ionic radii of $\mathrm{As}^{+5}$ in tetrahedral coordination and $\mathrm{O}^{2-}(0.335+1.4=1.735 \AA$; Shannon, 1976).

Another type of chain in the structure of II involves $\mathrm{SrO}_{11}$ coordination polyhedra, which are known as Edshammar polyhedra because this polyhedron was first described by Edshammar (1969). Each 11-vertex Edshammar polyhedron $\mathrm{SrO}_{11}$ consists of a trigonal bipyramid $\mathrm{SrO}_{5}$ (two $\mathrm{O}$ atoms at apices, usually at the longest, and three $\mathrm{O}$ atoms in the equatorial plane, typically at the shortest $\mathrm{Sr}-\mathrm{O}$ distances) combined with the trigonal, rather 
deformed, prism $\mathrm{SrO}_{6}$ (Fig. 3b). Therefore, the strontium coordination polyhedron $\mathrm{SrO}_{11}$ can be described as a combination of a trigonal bipyramid and trigonal prism centred by the same $\mathrm{Sr}$ atom surrounded by 11 oxygen atoms at distances ranging from 2.567(11) to $3.102(8) \AA$ in $\mathrm{Sr}_{10} \mathrm{O}_{11}$, from $2.574(10)$ to $3.048(8) \AA$ in $\mathrm{Sr}_{62 \mathrm{O}_{11}}$, from $2.650(8)$ to $3.091(4) \AA$ in $\mathrm{Sr} 71 \mathrm{O}_{11}$, from $2.568(11)$ to $3.017(11) \AA$ in $\mathrm{Sr} 63 \mathrm{O}_{11}$, from 2.561(12) to 3.035(11) $\AA$ in $\mathrm{Sr}_{64 \mathrm{O}_{11}}$ and from $2.695(5)$ to $3.087(7) \AA$ in $\mathrm{Sr}_{22} \mathrm{O}_{11}$. Observed values of $2.865,2.858,2.844,2.851,2.864$ and $2.861 \AA$ for the average $\langle\mathrm{Sr}-\mathrm{O}\rangle$ bond distances are very similar and close to the calculated value from effective ionic radii of $\mathrm{Sr}^{2+}$ cations with $\mathrm{CN}=11$ $(1.4+1.4=2.8 \AA)$. The value of $1.4 \AA$ for $\mathrm{Sr}^{2+}$ with $\mathrm{CN}=11$ was estimated from 1.36 and $1.44 \AA$ given by Shannon (1976) for $\mathrm{Sr}^{2+}$ with $\mathrm{CN}=10$ and $\mathrm{CN}=12$, respectively. In addition, this is consistent with recent work (Gagné and Hawthorne, 2016). By sharing common trapezoidal faces, each Edshammar polyhedron is linked to two similar neighbouring polyhedra. Each Edshammar polyhedron $\mathrm{SrO}_{11}$ shares four oxygen atoms (two from a trigonal bipyramid and two from a trigonal prism) with the neighbouring $\mathrm{SrO}_{11}$-polyhedron from one side, and additional four vertices from another side, in order to form trapezoidal face-sharing $\mathrm{SrO}_{11}$-chains (Fig. 3c).

The partial occupancy of mixed sites Sr71/O71 and Sr72/O72 by $\mathrm{Sr}$ are accompanied by the appearance of extra atoms (Fig. 3e) at distances less than $1 \AA$ from Sr71 (Sr81 and Sr82) and Sr72 (Sr83 and Sr84). The four additional 11-coordinated Sr81-Sr84 atoms are of very low occupancy (ca. 10\% of available sites) and are surrounded by oxygen atoms in a similar way, like Sr71 and Sr72 atoms (Table S5). Some displacement ellipsoids of these oxygen atoms have a small problematic form indicating a disorder in this part of structure.

Similar to in $\mathbf{I}$ the 8-coordinated $\mathrm{Sr}^{2+}$ cations are situated in holes between the layers of octahedral chains linked by $\mathrm{AsO}_{4}$ tetrahedra (Fig. 3a). For 8-coordinated $\mathrm{Sr}^{2+}$ cations the bond lengths Sr11-O, Sr21-O and Sr22-O vary in the intervals 2.507(7)-2.789(8), 2.512(11)-3.081(10) and 2.496(7)-3.090(9) $\AA$, respectively. The average $\left\langle\mathrm{Sr}^{2+}-\mathrm{O}\right\rangle$ bond distances are similar: $2.663,2.656$ and $2.651 \AA$ for $\langle$ Sr $11-\mathrm{O}\rangle,\langle\mathrm{Sr} 21-\mathrm{O}\rangle$ and $\langle\mathrm{Sr} 22-\mathrm{O}\rangle$, respectively, which is very close to the calculated value from effective ionic radii of 8 -coordinated $\mathrm{Sr}^{2+}$ cations $(1.26+1.4=2.66 \AA$; Shannon, 1976) and mean bond length of $2.656 \AA$ given by Gagné and Hawthorne (2016). The $\mathrm{Sr}_{11 \mathrm{O}_{8}}$ polyhedron, having four shorter and four longer $\mathrm{Sr}-\mathrm{O}$ distances, can be described as an intermediate between the considerably distorted orthorhombic prism and the tetragonal elongated double split octahedron with the four axial bonds longer $(<2.795>\AA)$ than the four equatorial bonds $(<2.531>\AA)$. Another two strontium atoms display a bicapedoctahedral geometry with six shorter $(<2.543>$ and $<2.540>\AA)$ and two longer bonds $\left(<2.993>\right.$ and $<2.984>\AA$ in $\mathrm{Sr}_{2} 1 \mathrm{O}_{8}$ and $\mathrm{Sr} 22 \mathrm{O}_{8}$, respectively). The four next-nearest oxygen atoms are more than $3.5 \AA$ away from the central Sr11, Sr21 and Sr22 atoms.

The difference-Fourier map did not reveal the positions of the $\mathrm{H}$ atoms. This was expected considering their amount, as well as the substitutional and positional disorder of Sr. Therefore the hydrogen-bonding system is complex. However, bond-valence calculations (Brown and Altermatt, 1985, Brese and O'Keeffe, 1991) show that the $\mathrm{Sr}-\mathrm{O}, \mathrm{Fe}-\mathrm{O}$ and $\mathrm{As}-\mathrm{O}$ bond lengths are consistent with the presence of 8-coordinated and 11-coordinated $\mathrm{Sr}^{2+}$, 6-coordinated $\mathrm{Fe}^{3+}$, 4-coordinated $\mathrm{As}^{5+}$ and $\mathrm{O}^{2-}\left(\Sigma v_{\mathrm{ij}}=\right.$ 1.988(1), 2.100(7) and 2.126(9) vu for Sr11, Sr21 and Sr22, $\Sigma v_{\mathrm{ij}}=3.072(3), 3.106(3), 3.007(0)$ and 2.994(1) vu for Fel1$\mathrm{Fe} 14, \Sigma v_{\mathrm{ij}}=5.043(3), 5.086(2), 4.987(2), 4.890(2), 5.050(2)$ and 5.083(1) vu for As11-As14, As21 and As22). The bond valence sums $\Sigma v_{\mathrm{ij}}$ for O61-O64, O71 and O72 without the contributions of $\mathrm{H}$ are close to 1 , while that of $\mathrm{O} 31-\mathrm{O} 34$ are near $1.6 \mathrm{vu}$ indicating that they are involved in hydrogen bonding (Table S8). Except $\mathrm{O} 23$ and $\mathrm{O} 24$, the calculated bond valence sums for the other oxygen atoms were $\approx 2$ indicating that they hardly participate in hydrogen-bonding interactions. The small undersaturation of O23 and O24 can be the result of a positional and substitutional disorder, i.e. the displacements of O23 and O24 oxygen atoms due to the substitutions of differently sized and charged ions (Sr72 and O72) and their amounts in the coordination sphere as well as the positional disorder of Sr72.

The four $\mathrm{OH}$ groups (O61H61-O64H64) act as hydrogenbond donors to the oxygen atoms O31-O34 $(D \cdots A$ distances are in the range $2.721(10)-2.748(8) \AA$ and $D-H \cdots A$ angles are from $151(4)-155(5)^{\circ}$. Another two $\mathrm{OH}$ groups $(\mathrm{O} 71 \mathrm{H} 71$ and $\mathrm{O} 72 \mathrm{H} 72$ ) are alternately single hydrogen bond donors and acceptors to one another $(D \cdots A$ distance is $2.695(5) \AA$ and $D-H \cdots A$ angles are $147(3)$ and $145(3)^{\circ}$, respectively). All these hydrogen bonds are of average strength (Table 7 ).

It should be kept in mind that $\mathrm{O} 72$ has $97 \%$ occupancy, O71 has $63 \%$ and that they can be single hydrogen-bond donors and acceptors to one another in a maximum $50 \%$ of unit cells. If O71 and $\mathrm{O} 72$ are always protonated, which oxygen atoms can act as hydrogen-bond acceptors? The nearest neighbours of $\mathrm{O} 72$ and O71 are O11-O14 (interatomic distances O72-O12, O72-O11 ${ }^{v i i}$, $\mathrm{O} 71-\mathrm{O} 13^{x}$ and O71-O14 are 2.969(11), 2.979(11), 3.042(9) and 3.032(9) $̊$; symmetry codes: (vii) $x, y, z-1$; (x) $x, y, z+1$ ) indicating possible weak hydrogen bonds. The bond valence sums for O11O14 are 2.102, 2.111, 2.087 and $2.052 \mathrm{vu}$. The slight oversaturation at the O11-O14 sites, coupled with the very small contributions of hydrogen bonds, could be interpreted as due to disorder and limitations of bond-valence analysis (Figs 3d, e).

Crystal structure of $\mathrm{SrFe}\left(\mathrm{AsO}_{4}\right)\left(\mathrm{AsO}_{3} \mathrm{OH}\right)$ (III).

In contrast to I and II, in the structure of III the $\mathrm{FeO}_{6}$ octahedra are completely isolated from one another by the surrounding arsenate tetrahedra. This arrangement produces unique metal arsenate octahedral-tetrahedral-quadruple chains, which are composed of one central double and two peripheral single chains extended along the $a$ axis (Fig. 4a). The central double chain is built up of alternating corner-sharing $\mathrm{Fe} \mathrm{O}_{6}$ octahedra and $\mathrm{As} \mathrm{O}_{4}$ tetrahedra. The two sides of the double chain are 'out of phase' meaning that $\mathrm{Fe} \mathrm{O}_{6}$ octahedra in one side are arranged in a line with, and are linked to, $\mathrm{AslO}_{4}$ tetrahedra on the other side. The peripheral single chains are made up of alternating corner-sharing $\mathrm{Fe} 2 \mathrm{O}_{6}$ octahedra and $\mathrm{As}_{2} \mathrm{O}_{4}$ tetrahedra, which are also 'out of phase' with regard to the central double chain. These octahedral-tetrahedral-quadruple chains are centred around the inversion centre at $(0,0,0)$ with one single and one half of a double chain on each side (Fig. $4 \mathrm{~b}$ ). The chains are further linked by $\mathrm{As}_{3} \mathrm{O}_{4}$ tetrahedra to form a slab parallel to the (010) plane. A slab is placed between the relative heights, $y$, from approximately -0.35 to 0.35 (Fig. 4b). The threedimensional structure is formed by interconnected slabs through bridging $\mathrm{As}_{4} \mathrm{O}_{4}$ tetrahedra and hydrogen bonds. The adjacent slabs are linked additionally to each other via bonds to $\mathrm{Sr}^{2+}$ cations, which are accommodated inside the channels of the hetero-polyhedral three-dimensional open framework.

The slightly distorted $\mathrm{Fe} 1 \mathrm{O}_{6}$ and $\mathrm{Fe} 2 \mathrm{O}_{6}$ octahedra share all six corners with adjacent arsenate tetrahedra. The individual Fe1-O bond lengths vary from $1.926(9)$ to $2.107(10) \AA$, while Fe2-O bond lengths vary from $1.948(9)$ to $2.126(9) \AA$ (Table 5). The 
(a)

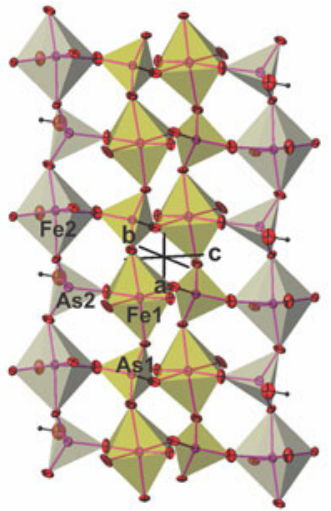

(b)

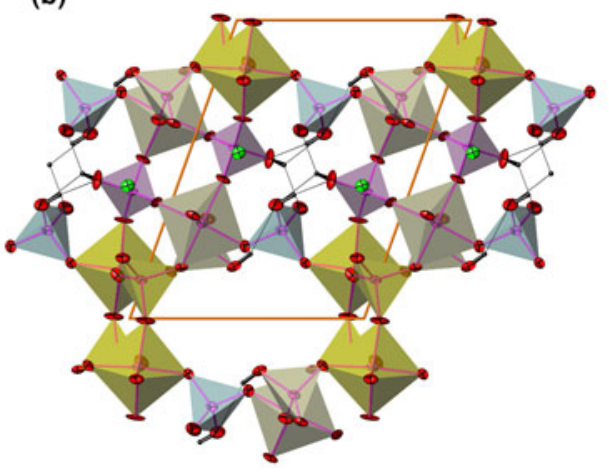

(c)

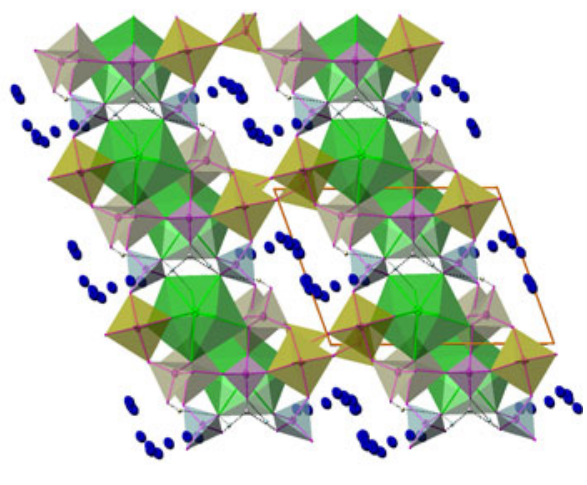

Fig. 4. Projection of a single octahedral-tetrahedral-quadruple chain showing $4 \mathrm{M}$ rings generated from the vertices of $\mathrm{AsO}_{4}$ tetrahedra and Fe $\mathrm{O}_{6}$ octahedra. Double central chain is yellow, single-peripheral chains are grey. $\mathrm{H}$ atoms are presented as small spheres of arbitrary radii; (b) the linkages of quadruple chains into slabs projected along [100] direction ( $b$ is horizontal); (c) projection of III along the $a$-axis showing the channels where Sr2 (small blue ellipsoids) is statistically positioned in 20 sites. The $\mathrm{Sr}_{2} \mathrm{O}_{16}$ dimers are green ( $c$ is horizontal); $\mathrm{H}$ atoms are presented as small spheres and $\mathrm{H}$ bonds are shown as broken lines.

average $<\mathrm{Fe}^{3+}-\mathrm{O}>$ bond distances are similar: 2.016 and $2.002 \AA$ for $\langle\mathrm{Fe} 1-\mathrm{O}\rangle$ and $\langle\mathrm{Fe} 2-\mathrm{O}\rangle$, respectively. These average values are close to the calculated from effective ionic radii of 6 -coordinated $\mathrm{Fe}^{3+}$ ions $(0.65+1.4=2.05 \AA$; Shannon, 1976).

Although the mean $<$ As-O $>$ bond lengths are almost the same for all arsenate tetrahedra $(<$ As1-O $\rangle=1.679,\langle$ As2 $-\mathrm{O}\rangle=1.683$, $\langle$ As3-O $\rangle=1.682$ and $\langle$ As4-O $\rangle=1.686 \AA$ ), the individual bond lengths vary from $1.657(10)$ to $1.698(10)$, from $1.657(9)$ to $1.714(10)$, from $1.653(9)$ to $1.722(10)$ and from $1.655(9)$ to 1.720(10) A for As1-O, As2-O, As3-O and As4-O, respectively. These average distances are close to the sum of the effective ionic radii of $\mathrm{As}^{+5}$ in tetrahedral coordination and $\mathrm{O}^{2-}(0.335+1.4=$ $1.735 \AA$ Å; Shannon, 1976).

Strontium cations are also linked by sharing $\mathrm{O}$ and $\mathrm{OH}$ groups. The Srl atoms are located inside the small channels extending nearly along [010]. The channels are centred on the inversion centre at $0.5,0.5,0.5$ and are bounded by octahedral-tetrahedral chains with $\mathrm{As}_{3} \mathrm{O}_{4}$ and $\mathrm{As}_{4} \mathrm{O}_{4}$ tetrahedra. By sharing a common two symmetry-equivalent oxygen atom $\mathrm{O} 23$, two 9-coordinated $\mathrm{Sr} 1$ form a $\mathrm{Sr}_{2} \mathrm{O}_{16}$ dimer. The nine $\mathrm{Sr}-\mathrm{O}$ distances range from 2.473(10) to 3.120(9) A.

The Sr2 atoms inside the large channels along [100] are highly mobile in the crystal lattice. They appear distributed among ten positions in the channels. These Sr21-Sr30 positions are too close to be occupied simultaneously and therefore $\mathrm{Sr} 2$ atoms are actually distributed randomly over ten pairs of symmetry-equivalent sites. The site occupancy factors of the four most occupied positions are refined to $0.210(6), 0.225(6), 0.140(6)$ and $0.113(6)$. The other positions have less than $10 \%$ occupancy.

As expected, the As- $\mathrm{OH}$ bond distances are slightly elongated in comparison to the other As-O bonds in tetrahedra. One $\mathrm{OH}$ group $(\mathrm{O} 24 \mathrm{H} 24)$ acts as a hydrogen-bond donor to the oxygen $\mathrm{O} 44$ from the other $\mathrm{OH}$ group $(D \cdots A$ distance is $3.114(16) \AA$ and $D-H \cdots A$ angle is $\left.153^{\circ}\right)$. Another two hydrogen bonds are bifurcated. The $\mathrm{H}$-bond donor $\mathrm{O} 34$ is bound to two H-bond acceptors, $\mathrm{O} 43$ and O44, at $D \cdots A$ distances of $2.631(16)$ and $2.833(15) \AA$, respectively. Both are bent with $D-\mathrm{H} \cdots A$ angles of 137 and $128^{\circ}$. Similarly, the other H-bond donor $\mathrm{O} 44$ is bound to two H-bond acceptors, O34 and O43, at the comparable $D \cdots A$ distances of 2.833(15) and $3.123(14) \AA$, respectively, which are also bent $(D-H \cdots A$ angles are 152 and $125^{\circ}$ ). Because hydrogen atoms $\mathrm{H} 34$ and $\mathrm{H} 44$ were found in general positions at a short distance of $1.48 \AA$ their occupancy factors were fixed at 0.5. All these hydrogen bonds are of average to weak strength (Table 8).

Bond-valence calculations (Brown and Altermatt, 1985; Brese and O'Keeffe, 1991) show that the $\mathrm{Fe}-\mathrm{O}, \mathrm{As}-\mathrm{O}$ and $\mathrm{Sr}-\mathrm{O}$ bond lengths are consistent with the presence of $\mathrm{Fe}^{3+}, \mathrm{As}^{5+}, \mathrm{Sr}^{2+}$ and $\mathrm{O}^{2-} \Sigma v_{\mathrm{ij}}=3.028(1)$ vu for Fe1, $\Sigma v_{\mathrm{ij}}=3.151(5)$ vu for $\mathrm{Fe} 2$ with $\mathrm{CN}=6, \Sigma v_{\mathrm{ij}}=5.085(1), \Sigma v_{\mathrm{ij}}=5.032(1), \Sigma v_{\mathrm{ij}}=5.040(1)$ and $\Sigma v_{\mathrm{ij}}=$ 4.986(2) vu for As1, As2, As3 and As4, respectively, with $\mathrm{CN}=$ 4 and $\Sigma v_{\mathrm{ij}}=2.024(2) \mathrm{vu}$ for $\mathrm{Sr}^{2+}$ with $\mathrm{CN}=10$. Taking into account the contribution of the non-hydrogen atoms excluding Sr2, the oxygens, which are included in hydrogen bonding, are, as expected, undersaturated: $\Sigma v_{\mathrm{ij}}$ are 1.154, 1.311, 1.473 and $1.418 \mathrm{vu}$ for O24, O34, O43 and O44, respectively (Table S9). Keeping in mind that $\mathrm{O} 24$ is a single hydrogen bond donor towards $\mathrm{O} 44, \mathrm{O} 43$ is a double acceptor from $\mathrm{O} 34$ and $\mathrm{O} 44$ and $\mathrm{O} 34$ and $\mathrm{O} 44$ are alternately single hydrogen bond donors and acceptors to one another, the bond valence values are very well balanced. The bond valence sums for other oxygen atoms are very close to the nominal valence of $2^{-}$, or they are slightly lower indicating that they are bonded to disperse Sr2.

\section{Raman spectroscopy}

In all $\mathrm{Sr} M$-arsenate hydrates $\left(M=\mathrm{Ni}^{2+}\right.$ and $\left.\mathrm{Fe}^{3+}\right)$ presented in this study, Raman bands in the $1000-600 \mathrm{~cm}^{-1}$ region are assigned to the symmetric and antisymmetric stretching modes of the $\left(\mathrm{AsO}_{4}\right)^{3-}$ and/or $\left(\mathrm{AsO}_{3} \mathrm{OH}\right)^{2-}$ groups, whereas internal bending vibrations of these tetrahedra are observed below $550 \mathrm{~cm}^{-1}$, were they are partially overlaid by various external and lattice modes.

Raman spectra of $\mathbf{I}$ are shown on Fig. 5 together with Raman spectra of $\mathrm{SrCo}_{2}\left(\mathrm{AsO}_{4}\right)\left(\mathrm{AsO}_{3} \mathrm{OH}\right)(\mathrm{OH})\left(\mathrm{H}_{2} \mathrm{O}\right)$ (Mihajlović and Effenberger, 2004) and Raman spectra of the mineral tsumcorite, $\mathrm{PbZn}_{2}\left(\mathrm{AsO}_{4}\right)_{2} \cdot 2 \mathrm{H}_{2} \mathrm{O}$ (RRUFF database: R100185, https://ruff. info/). $\mathrm{SrCo}_{2}\left(\mathrm{AsO}_{4}\right)\left(\mathrm{AsO}_{3} \mathrm{OH}\right)(\mathrm{OH})\left(\mathrm{H}_{2} \mathrm{O}\right)$ was synthesised in the scope of previous work of the first author of this paper, but its Raman spectra are presented here for the first time (vs = very strong, $\mathrm{s}=$ strong, $\mathrm{m}=$ medium, $\mathrm{w}=$ weak, $\mathrm{sh}=$ shoulder). In the $1000-700 \mathrm{~cm}^{-1}$ range, I shows the As-O stretching modes of the $\left(\mathrm{AsO}_{4}\right)^{3-}$ groups at: $870(\mathrm{sh}, \mathrm{s}), 828$ (vs), $776(\mathrm{~m})$ and $741(\mathrm{w}) \mathrm{cm}^{-1}$, which compare very well with the spectra of isostructural mineral tsumcorite, having its characteristic Raman bands at 870 (vs), 827 (s) and $734(\mathrm{~s}) \mathrm{cm}^{-1}$. The Raman spectra 


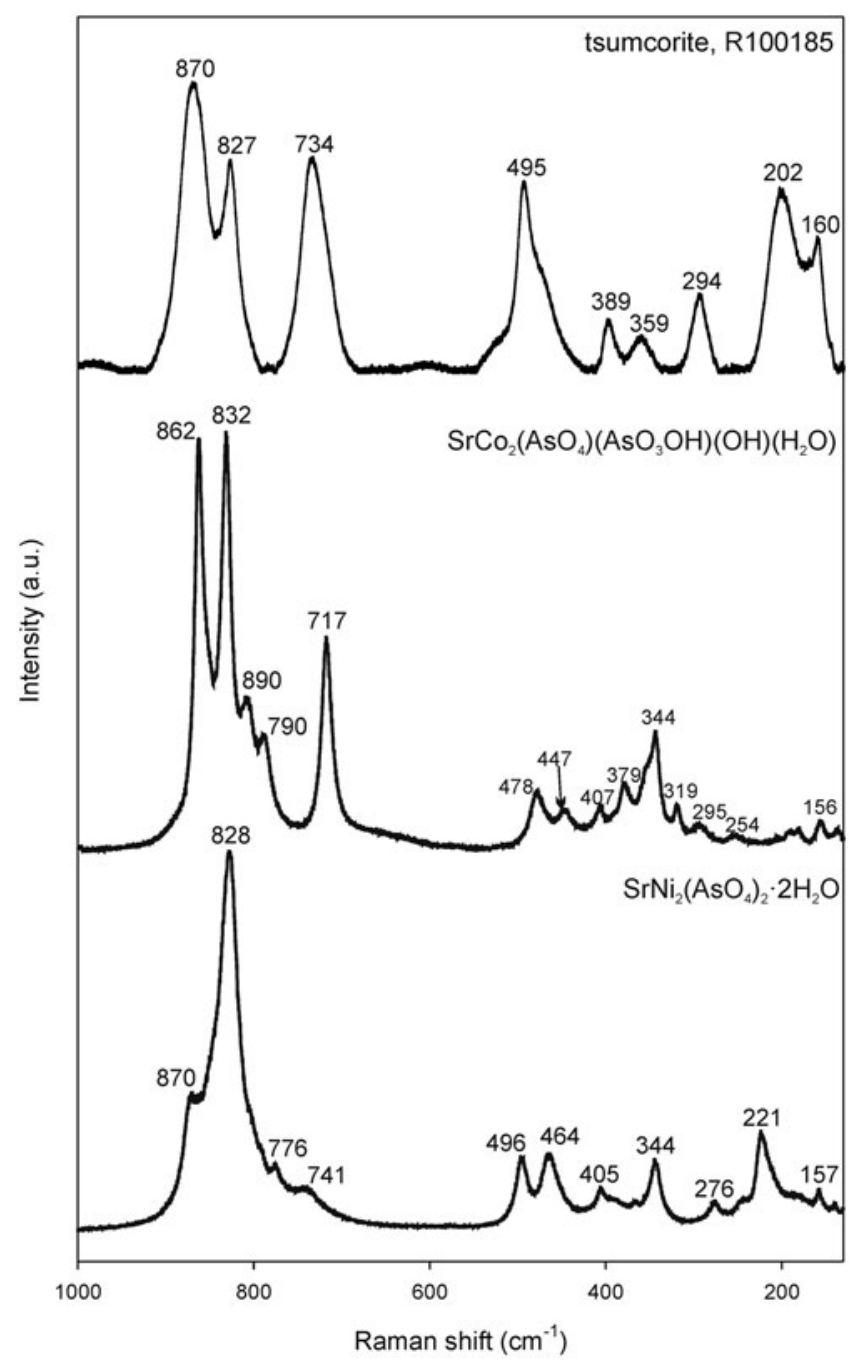

Fig. 5. Raman spectra of $\mathbf{I}$, compared with Raman spectra of the mineral tsumcorite (RRUFF ID: R100185) and $\mathrm{SrCO}_{2}\left(\mathrm{AsO}_{4}\left(\mathrm{AsO}_{3} \mathrm{OH}\right)(\mathrm{OH})\left(\mathrm{H}_{2} \mathrm{O}\right)\right.$ (Mihajlović and Effenberger, 2004).

of the SrCo-arsenate are more complex due to the lowering of the space-group symmetry to $P 2_{1} / a$ and the introduction of the protonated $\left(\mathrm{AsO}_{3} \mathrm{OH}\right)^{2-}$ group. In the As-O stretching region the SrCo-arsenate shows characteristic Raman bands at 862 (vs), 832 (vs), 890 (sh, m), 790 (sh, m) and 717 (s) $\mathrm{cm}^{-1}$.

Raman spectra of II are characterised with the As-O symmetric and antisymmetric stretching modes of the $\left(\mathrm{AsO}_{4}\right)^{3-}$ groups at 916 (sh, w), 864 (vs), 851 (vs) and $814(\mathrm{~s}) \mathrm{cm}^{-1}$. The band at $740(\mathrm{~m}) \mathrm{cm}^{-1}$ may be attributed to the hydroxyl deformation mode (Fig. 6). They are compared to the Raman spectra of structurally related carminite, $\mathrm{PbFe}^{3+}\left(\mathrm{AsO}_{4}\right)_{2}(\mathrm{OH})_{2}$ (RRUFF data base: R061061; https://rruff.info/) and arsenbrackebuschite, $\mathrm{Pb}_{2}\left(\mathrm{Fe}^{3+}\right.$, $\mathrm{Zn})\left(\mathrm{AsO}_{4}\right)_{2}\left(\mathrm{OH}, \mathrm{H}_{2} \mathrm{O}\right)$ (RRUFF database: R100184; https://rruff. info/). In the region $1000-600 \mathrm{~cm}^{-1}$, the new compound II is more similar to carminite, then brackebuschite, which was also confirmed by the structural analysis.

Raman spectra of III reflect the complexity of the crystal structure. The considerably large number of bands, which cannot be certainly specified, are caused by the four crystallographically different $\mathrm{AsO}_{4}$ tetrahedra (of which three are protonated $\mathrm{AsO}_{3} \mathrm{OH}$ groups). Spectral data on orthoarsenates that have been published

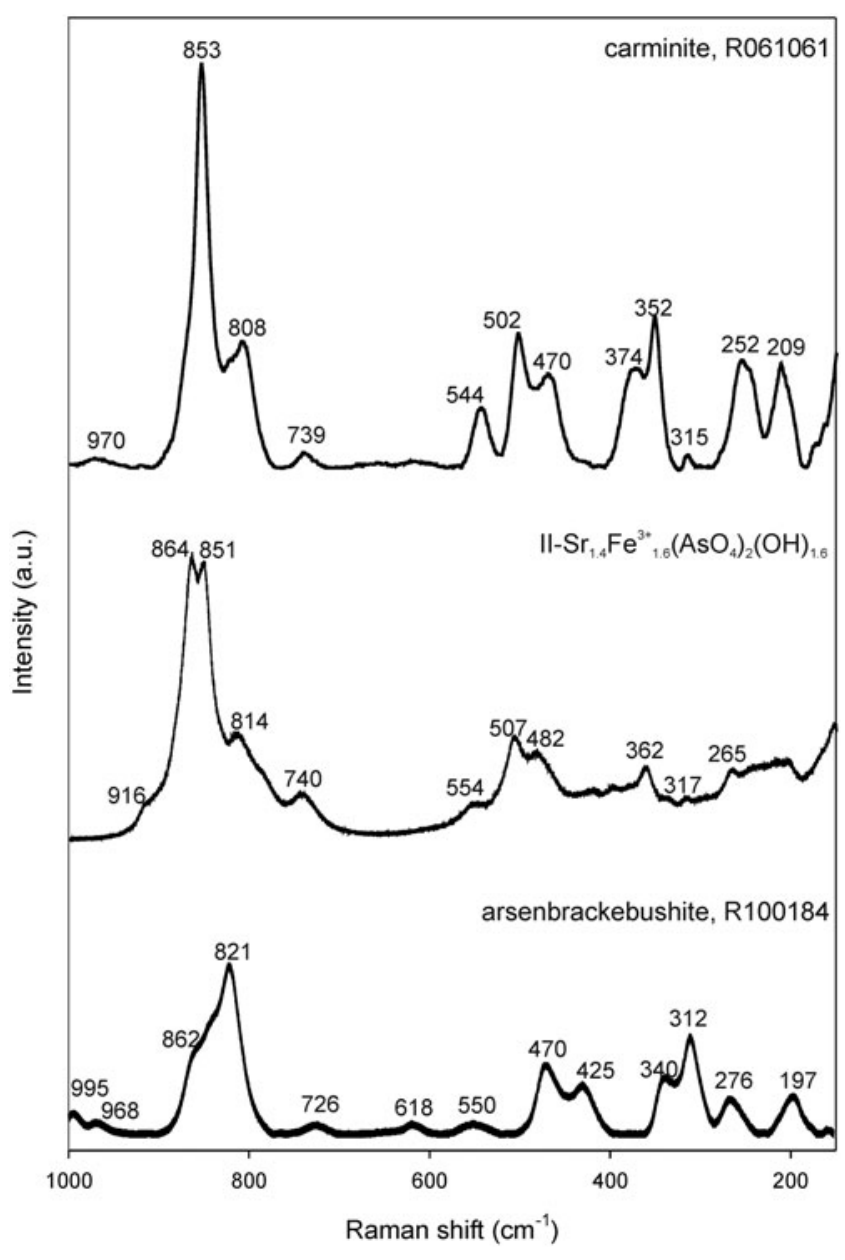

Fig. 6. Raman spectra of II, compared with Raman spectra of the carminite (RRUFF ID: R061061) and arsenbrackebuschite (RRUFF ID: 100184).

previously are, so far, somewhat incomplete and not in good agreement with each other. Therefore, attempts to compare with them failed. However, the distinct frequency ranges may be assigned as follows:

Based on the $d-v$ correlation for hydrogen bonds (Libowitzky, 1999), the Raman-shift values observed in the O-H stretching region are in very good agreement with the refined $\mathrm{O}-\mathrm{H} \cdots \mathrm{O}$ bond lengths ranging between 2.63(2) and 3.12(1) $\AA$ (corresponding Raman bands obtained between 2500 and $3700 \mathrm{~cm}^{-1}$ ) (Fig. 7).

The $1000-700 \mathrm{~cm}^{-1}$ range shows the As-O stretching modes of the $\left(\mathrm{AsO}_{3} \mathrm{OH}\right)^{2-}$ and $\left(\mathrm{AsO}_{4}\right)^{3-}$ groups at: $934(\mathrm{sh}, \mathrm{m}), 915(\mathrm{vs}), 901(\mathrm{sh}, \mathrm{m})$, $881(\mathrm{~m}), 40(\mathrm{sh}, \mathrm{s}), 824(\mathrm{~s}), 790(\mathrm{sh}, \mathrm{m}), 775(\mathrm{~m})$ and $733(\mathrm{w}) \mathrm{cm}^{-1}$. The most intense Raman bands at $\sim 915,840$ and $824 \mathrm{~cm}^{-1}$ correspond to the stretching vibrations of $\left(\mathrm{AsO}_{3} \mathrm{OH}\right)^{2-}$ and $\left(\mathrm{AsO}_{4}\right)^{3-}$ groups.

\section{Structural relations to the associated minerals and inorganic compounds}

$\mathrm{SrNi}_{2}\left(\mathrm{AsO}_{4}\right)_{2} \cdot 2 \mathrm{H}_{2} \mathrm{O}$ (I), is isostructural with minerals of the tsumcorite group, which adopt the monoclinic symmetry, space group $C 2 / m(Z=2)$. The general formula of the tsumcorite group is $A\left(M^{2+, 3+}\right)_{2}\left(X_{4}\right)_{2}\left(\mathrm{H}_{2} \mathrm{O}, \mathrm{OH}\right)_{2}$ ( $A$ is a large cation, $M^{2+, 3+}$ is usually an octahedrally coordinated transition metal cation and $X$ is a tetrahedrally coordinated small cation). The 


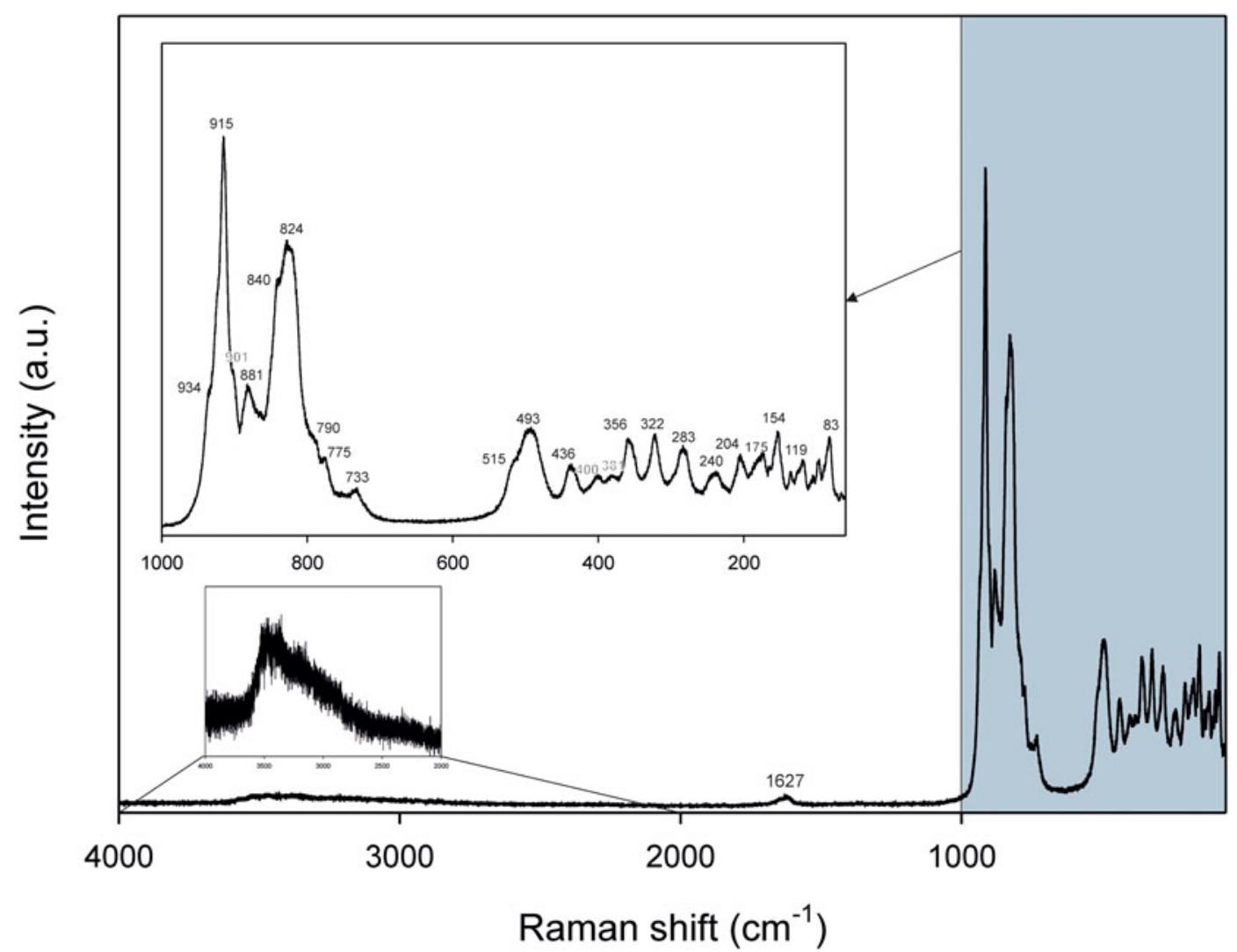

Fig. 7. Raman spectrum of III.

minerals of this group have been described with $\mathrm{Pb}, \mathrm{Ca}, \mathrm{Bi}$ and $\mathrm{Na}$ on the $A$ site, $\mathrm{Zn}, \mathrm{Fe}^{3+}, \mathrm{Cu}^{2+}, \mathrm{Mn}^{3+}$ and $\mathrm{Co}$ on the $M$ site, and $\mathrm{As}^{5}$ ${ }^{+}, \mathrm{P}^{5+}, \mathrm{V}^{5+}$ and $\mathrm{S}^{6+}$ on the $X$ site (Tillmanns and Gebert, 1973; Pring et al., 1989; Kharisun et al., 1997; Krause et al., 1998, 2001a, 2001b, 2002; Effenberger et al., 2000; Brugger et al., 2000, 2001; 2002; Yang et al., 2012; Elliott and Pring, 2015; Pekov et al., 2016). They display either monoclinic or triclinic symmetry, depending on the chemical composition as well as ordering of the hydrogen bonds and cations on the $M$ sites. The basic tsumcorite-type structure mentioned previously is monoclinic (space group $C 2 / m, Z=2$ ) and represents the parental structure of the group referred to as tsumcorite-type structure. It was determined by Tillmanns and Gebert (1973). The majority of the tsumcorite-group minerals (Table 9) crystallise in space group $\mathrm{C} 2 / \mathrm{m}$, but some members display lower symmetry. The next modification is also monoclinic referred to as the Sr-Co-type structure. It is characterised by protonated anion tetrahedra (Mihajlović and Effenberger, 2004) and a doubled cell volume $(Z=4)$. In addition, the space-group symmetry is lowered to the $P 2_{1} / a$. The triclinic members of the tsumcorite group (Table 9) crystallise in space group $P \overline{1}(Z=1)$ and can be divided into the helmutwinklerite and rappoldite subgroup (Effenberger et al., 2000). In the helmutwinklerite subgroup, referred to as a helmutwinklerite-type structure, the symmetry reduction is due to the ordering of the hydrogen bonds. The characteristic of this subgroup is two $\mathrm{H}_{2} \mathrm{O}$ per formula unit and the hydrogen atoms are rearranged in order to avoid the symmetry-restricted hydrogen bonds. These changes in hydrogen bonding induce structural transformations that cause the transition from the monoclinic tsumcorite-type structure to the triclinic helmutwinklerite-type structure (Krause et al., 1998, 2001b; Effenberger et al., 2000; Elliott and Pring, 2015). In the second triclinic subgroup, referred to as the gartrellite type, symmetry reduction is due to the cation ordering on the two $M$ positions in the triclinic unit cell.

The compound II, $\mathrm{Sr}_{1.4} \mathrm{Fe}_{1.6}\left(\mathrm{AsO}_{4}\right)_{2}(\mathrm{OH})_{1.6}$ adopts a novel intermediate crystal structure between carminite and arsenbrackebuschite, nominally $\mathrm{PbFe}_{2}^{3+}\left(\mathrm{AsO}_{4}\right)_{2}(\mathrm{OH})_{2}$ and $\mathrm{Pb}_{2} \mathrm{Fe}^{3+}$ $\left(\mathrm{AsO}_{4}\right)_{2}(\mathrm{OH})$, respectively (Donaldson et al. 1955; Finney, 1963; Hofmeister and Tillmanns, 1978; Olmi and Sabelli, 1995; Kharisun et al., 1996; Foley et al., 1997; Gonzalez del Tanago et al., 2003; Sanjeewa et al., 2015; Lafuente and Downs, 2016; Table 10). Carminite is also related structurally to the phosphate analogue crimsonite, $\mathrm{Pb}^{2+} \mathrm{Fe}_{2}^{3+}\left(\mathrm{PO}_{4}\right)_{2}(\mathrm{OH})_{2}$ and the $\mathrm{Ca}$ analogue sewardite, $\mathrm{Ca}^{2+} \mathrm{Fe}_{2}^{3+}\left(\mathrm{AsO}_{4}\right)_{2}(\mathrm{OH})_{2}$ (Kampf et al., 2016; Roberts et al., 2002). Mawbyite, nominally $\mathrm{Pb}^{2+} \mathrm{Fe}_{2}^{3+}\left(\mathrm{AsO}_{4}\right)_{2}(\mathrm{OH})_{2}$, is a dimorph of carminite (the same formula, but different structure) and $\mathrm{Fe}$ analogue of tsumcorite (Kharisun et al., 1997, Pring et al., 1989, Table 10). One of the main differences between these three structures is the $A: M^{3+}$ ratio, which is $1: 2$ for carminite, 1.00:1.14 for II and 1.0:0.5 for arsenbrackebuschite. These structures are also related to previously mentioned tsumcorite, nominally $\mathrm{PbFe}_{2}^{2+}\left(\mathrm{AsO}_{4}\right)_{2} \cdot 2 \mathrm{H}_{2} \mathrm{O}$, both in chemical composition and in structure properties. Carminite and tsumcorite have the same general formula $A\left(M^{2+, 3+}\right)_{2}\left(\mathrm{XO}_{4}\right)_{2}\left(\mathrm{H}_{2} \mathrm{O}, \mathrm{OH}\right)_{2}$. The changing of the cation valence and size in the octahedral sites from basically $\mathrm{M}^{3+}$ in carminite to $\mathrm{M}^{2+}$ in tsumcorite causes changes in the octahedral chains, which are the main building units. The presence of 


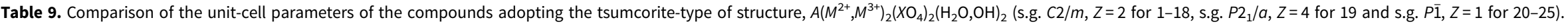

\begin{tabular}{|c|c|c|c|c|c|c|c|}
\hline & Formula, mineral name & $a(\AA)$ & $b(\AA)$ & $c(\AA)$ & $\alpha / \beta / \gamma\left({ }^{\circ}\right)$ & Volume $\left(\AA^{3}\right)$ & Reference \\
\hline 1 & $\left.\mathrm{~Pb}\left(\mathrm{Zn}_{0.5} \mathrm{Fe}_{0.12}^{2+} \mathrm{Fe}_{0.38}^{3+}\right)_{2}\left(\mathrm{AsO}_{4}\right)_{2}\left[(\mathrm{OH})_{0.38}\left(\mathrm{H}_{2} \mathrm{O}\right)_{0.62}\right)\right]_{2}$ tsumcorite & $9.124(3)$ & $6.329(2)$ & $7.577(2)$ & $115.28(3)$ & $395.5(4)$ & Tillmanns and Gebert (1973) \\
\hline 2 & $\mathrm{~Pb}\left(\mathrm{Co}_{0.39} \mathrm{Fe}_{0.37} \mathrm{Ni}_{0.20} \mathrm{Zn}_{0.02} \mathrm{Al}_{0.02}\right)_{2}\left(\mathrm{AsO}_{4}\right)_{2}\left[(\mathrm{OH})_{0.39}\left(\mathrm{H}_{2} \mathrm{O}\right)_{0.61}\right]_{2}$ cobalttsumcorite & $9.097(2)$ & $6.313(2)$ & $7.555(3)$ & $115.08(2)$ & 393.0(1) & Krause et al. (2001a) \\
\hline 3 & $\left.\left(\mathrm{~Pb}_{0,7} \mathrm{Ca}_{0,3}\right)\left(\mathrm{Ni}_{1,36} \mathrm{Fe}_{0.49}^{3+} \mathrm{Zn}_{0.06} \mathrm{Mn}_{0.04}^{3+} \mathrm{Mg}_{0.04} \mathrm{Co}_{0.01}\right)\left(\mathrm{AsO}_{4}\right)_{2}(\mathrm{OH})_{0.53}\left(\mathrm{H}_{2} \mathrm{O}\right)_{0.47}\right]_{2}$ nickeltsumcorite & $9.124(8)$ & $6.339(3)$ & $7.567(7)$ & $115.19(6)$ & $396.0(7)$ & Pekov (2016) \\
\hline 4 & $\mathrm{~Pb}\left(\mathrm{Fe}_{1.5}^{3+} \mathrm{Zn}_{0.5}\right)\left(\mathrm{AsO}_{4}\right)_{2}\left[(\mathrm{OH})_{1.5}\left(\mathrm{H}_{2} \mathrm{O}\right)_{0.5}\right]_{2}$ mawbyite & $9.052(5)$ & $6.277(4)$ & $7.580(3)$ & $114.57(3)$ & $391.6(4)$ & Pring et al. (1989) \\
\hline 5 & $\mathrm{~Pb}\left(\mathrm{Fe}_{1.9}^{3+} \mathrm{Zn}_{0.07}\right)\left(\mathrm{AsO}_{4}\right)_{2}\left[(\mathrm{OH})_{1.93}\left(\mathrm{H}_{2} \mathrm{O}\right)_{0.07}\right]_{2}$ mawbyite & $9.066(4)$ & $6.286(3)$ & $7.564(3)$ & $114.857(5)$ & $391.1(3)$ & Kharisun et al. (1997) \\
\hline 6 & $\mathrm{Ca}\left(\mathrm{Zn}_{1.02}, \mathrm{Mn}_{0.98}\right)\left(\mathrm{AsO}_{4}\right)_{2}\left[(\mathrm{OH})_{0.49}\left(\mathrm{H}_{2} \mathrm{O}\right)_{0.51}\right]_{2}$ lotharmeyerite & $9.0727(6)$ & $6.2530(4)$ & $7.4150(5)$ & $116.739(4)$ & $375.68(4)$ & Yang et al. (2012) \\
\hline 7 & $\mathrm{Ca}\left(\mathrm{Fe}_{0.99} \mathrm{Zn}_{1.01}\right)\left(\mathrm{AsO}_{4}\right)_{2}\left[(\mathrm{OH})_{0.50}\left(\mathrm{H}_{2} \mathrm{O}\right)_{0.50}\right]_{2}$ ferrilotharmeyerite & $9.010(3)$ & $6.246(2)$ & $7.391(2)$ & $115.52(3)$ & 375.36 & Krause et al. (1998) \\
\hline 8 & $\mathrm{Ca}\left(\mathrm{Mn}_{0.59}^{3+} \square_{0.24} \mathrm{Mg}_{0.17}^{2+.}\right)_{2}\left\{\left(\mathrm{AsO}_{4}\right)_{0.76}\left[\mathrm{AsO}_{2}(\mathrm{OH})_{2}\right]_{0.24}\right\}_{2}\left[(\mathrm{OH})_{0.59}\left(\mathrm{H}_{2} \mathrm{O}\right)_{0.41}\right]_{2}$ manganlotharmeyerite & $9.043(1)$ & $6.2314(7)$ & 7.3889(9) & $116.392(2)$ & $372.97(9)$ & Brugger et al. (2002) \\
\hline 9 & $\left.\left(\mathrm{Ca}_{0.97} \mathrm{Bi}_{0.03}\right)\left(\mathrm{Ni}_{1.10} \mathrm{Fe}_{0.70} \mathrm{Co}_{0.20}\right)\left(\mathrm{AsO}_{4}\right)_{2}(\mathrm{OH})_{0.36}\left(\mathrm{H}_{2} \mathrm{O}\right)_{0.64}\right]_{2}$ nickellotharmeyerite & 9.005(1) & $6.205(1)$ & $7.411(1)$ & $115 / 31(1)$ & $374.4(1)$ & Krause et al. (2001a) \\
\hline 10 & $\mathrm{Ca}\left(\mathrm{Mgg}_{.78} \mathrm{Al}_{.82} \mathrm{Fe}_{.35} \mathrm{Mn}_{.05}\right)\left(\mathrm{AsO}_{4}\right)_{2}\left[(\mathrm{OH})_{0.61}\left(\mathrm{H}_{2} \mathrm{O}\right)_{0.39}\right]_{2}$ cabalzarite & $8.925(2)$ & $6.143(1)$ & $7.352(1)$ & $115.25(3)$ & $364.6(1)$ & Brugger et al. (2000) \\
\hline 11 & $\mathrm{Ca}\left(\mathrm{Mg}_{.82} \mathrm{Al}_{.84} \mathrm{Fe}_{.08} \mathrm{Mn}_{.26}\right)\left(\mathrm{AsO}_{4}\right)_{2}\left[(\mathrm{OH})_{0.59}\left(\mathrm{H}_{2} \mathrm{O}\right)_{0.41}\right]_{2}$ cabalzarite & $8.9284(5)$ & $6.1314(5)$ & $7.3439(6)$ & $115.494(7)$ & $362.9(1)$ & Brugger et al. (2000) \\
\hline 12 & $\left(\mathrm{Bi}_{0.65} \mathrm{Ca}_{0.35}\right)\left(\mathrm{Co}_{1.04} \mathrm{Ni}_{0.60} \mathrm{Fe}_{0.36}\right)\left(\mathrm{AsO}_{4}\right)_{2}\left[(\mathrm{OH})_{0.51}\left(\mathrm{H}_{2} \mathrm{O}\right)_{0.49}\right]_{2}$ schneebergite & $9.005(1)$ & $6.211(1)$ & $7.440(1)$ & $115.19(1)$ & $376.5(1)$ & Krause et al. (2002) \\
\hline 13 & $\left(\mathrm{Bi}_{0.55} \mathrm{Ca}_{0.45}\right)\left(\mathrm{Ni}_{1.00} \mathrm{CO}_{0.62} \mathrm{Fe}_{0.40}\right)\left(\mathrm{AsO}_{4}\right)_{2}\left[(\mathrm{OH})_{0.50}\left(\mathrm{H}_{2} \mathrm{O}\right)_{0.50}\right]_{2}\left(\mathrm{H}_{2} \mathrm{O}, \mathrm{OH}\right)_{2}$ nickelschneebergite & $8.995(1)$ & $6.207(1)$ & $7.462(1)$ & $115.00(1)$ & $377.6(1)$ & Krause et al. (2002) \\
\hline 14 & $\mathrm{PbCu}_{2}^{2+}\left(\left(\mathrm{As}_{1.23} \mathrm{~S}_{0.77}\right) \mathrm{O}_{4}\right)_{2}\left[(\mathrm{OH})_{0.38}\left(\mathrm{H}_{2} \mathrm{O}\right)_{0.62}\right]_{2}\left(\mathrm{H}_{2} \mathrm{O}, \mathrm{OH}\right)_{2}$ thometzekite & $9.077(8)$ & $6.300(8)$ & $7.661(8)$ & 116.99(8) & 390.38 & Krause et al. (1998) \\
\hline 15 & $\mathrm{PbFe}_{2}\left(\mathrm{VO}_{4}\right)_{2} \mathrm{~F}_{2}$ mounanaite & $9.294(8)$ & $6.166(7)$ & $7.713(8)$ & $115.57(6)$ & 398.72 & Krause et al. (1998) \\
\hline 16 & $\left(\mathrm{~Pb}_{0.83} \mathrm{Sr}_{0.17}\right) \mathrm{Mn}_{2}\left(\mathrm{VO}_{4}\right)_{2}(\mathrm{OH})_{2}$ krettnichite (from powder data) & $9.275(7)$ & $6.284(3)$ & $7.682(2)$ & $117.97(4)$ & $395.4(3)$ & Brugger et al. (2001) \\
\hline 17 & $\mathrm{SrNi}_{2}\left(\mathrm{PO}_{4}\right)_{2} \cdot 2 \mathrm{H}_{2} \mathrm{O}$ synthetic compound & $8.8877(3)$ & $6.0457(3)$ & $7.3776(3)$ & $114.173(2)$ & $361.66(3)$ & Assani et al. (2010) \\
\hline 18 & $\mathrm{SrNi}_{2}\left(\mathrm{AsO}_{4}\right)_{2} \cdot 2 \mathrm{H}_{2} \mathrm{O}$ synthetic compound & $9.173(3)$ & $6.2025(12)$ & $7.562(3)$ & $114.41(2)$ & $391.8(2)$ & This work (I) \\
\hline 19 & $\mathrm{SrCO}_{2}\left(\mathrm{AsO}_{4}\right)\left(\mathrm{AsO}_{3} \mathrm{OH}\right)(\mathrm{OH})\left(\mathrm{H}_{2} \mathrm{O}\right)$ synthetic compound & $9.139(2)$ & $12.829(3)$ & $7.522(2)$ & $114.33(3)$ & $803.6(3)$ & Mihajlović.and Effenberger (2004) \\
\hline 20 & $\mathrm{PbZn}_{2}\left(\mathrm{AsO}_{4}\right)_{2}\left(\mathrm{H}_{2} \mathrm{O}\right)_{2}$ helmutwinklerite & $5.606(2)$ & $5.610(2)$ & 7.617(1) & $\begin{array}{l}70.19(2) / 69.91(2) / \\
69.18(2)\end{array}$ & 203.77 & Krause et al. (1998) \\
\hline 21 & $\mathrm{~Pb}\left(\mathrm{CoNi}_{0.64} \mathrm{Zn}_{0.36}\right)\left(\mathrm{AsO}_{4}\right)_{2}\left(\mathrm{H}_{2} \mathrm{O}\right)_{2}$ rappoldite & $5.595(1)$ & $5.572(1)$ & $7.593(1)$ & $\begin{array}{l}70.19(1) / 70.41(1) / \\
69.23(1)\end{array}$ & 201.91 & Effenberger et al. (2000) \\
\hline 22 & $\mathrm{~Pb}\left(\mathrm{CuFe}^{3+}\right)\left(\mathrm{AsO}_{4}\right)_{2}\left[(\mathrm{OH})_{0.50}\left(\mathrm{H}_{2} \mathrm{O}\right)_{0.50}\right]_{2}$ gartrellite & $5.454(1)$ & $5.653(1)$ & $7.579(1)$ & $\begin{array}{l}67.52(1) / 69.27(1) / \\
70.08(1)\end{array}$ & 196.15 & Krause et al. (1998) \\
\hline 23 & $\mathrm{~Pb}\left(\mathrm{Zn}_{1.20} \mathrm{Cu}_{0.40} \mathrm{Fe}_{0.40}^{3+}\right)\left(\mathrm{AsO}_{4}\right)_{2}\left[(\mathrm{OH})_{0.40}\left(\mathrm{H}_{2} \mathrm{O}\right)_{0.60}\right]_{2}$ zincgartrellite & $5.550(1)$ & $5.620(1)$ & $7.621(1)$ & $\begin{array}{l}68.59(1) / 69.17(1) / \\
69.51(1)\end{array}$ & 200.10 & Effenberger et al. (2000) \\
\hline 24 & $\mathrm{PbCuAl}\left(\mathrm{AsO}_{4}\right)_{2}\left(\mathrm{OH}, \mathrm{H}_{2} \mathrm{O}\right)_{2}$ yancowinnaite & $5.444(2)$ & $5.640(2)$ & $7.518(2)$ & $\begin{array}{l}67.89(2) / 69.48(2) / \\
70.18(2)\end{array}$ & $194.51(7)$ & Elliott and Pring (2015) \\
\hline 25 & $\mathrm{CaCuFe}^{3+}\left(\mathrm{AsO}_{4}\right)_{2}\left[(\mathrm{OH})_{0.50}\left(\mathrm{H}_{2} \mathrm{O}\right)_{0.50]_{2}}\right.$ lukrahnite & $5.457(3)$ & $5.539(4)$ & $7.399(6)$ & $\begin{array}{l}68.43(5) / 68.90(4) / / \\
69.44(5)\end{array}$ & $187.8(1)$ & Krause et al. (2001b) \\
\hline
\end{tabular}


Table 10. Comparison of the unit-cell parameters of the compounds adopting carminite $\left[A\left(M^{2+}, M^{3+}\right)_{2}\left(X \mathrm{O}_{4}\right)_{2}\left(\mathrm{H}_{2} \mathrm{O}, \mathrm{OH}\right)_{2}\right.$, (s.g. CCcm, $Z=8$ for $\left.\left.1-7\right)\right]$ and arsenbrackebuschite $\left[A_{2}\left(M^{2+}, M^{3+}\right)\left(X_{4}\right)_{2}\left(\mathrm{H}_{2} \mathrm{O}, \mathrm{OH}\right)\right.$, (s.g. $P 2_{1} / m, Z=2$ for $\left.\left.10-15\right)\right]$ structure type.

\begin{tabular}{|c|c|c|c|c|c|c|c|}
\hline & Formula, mineral name & $a(\AA)$ & $b(\AA)$ & $c(\AA)$ & $\alpha / \beta / \gamma\left({ }^{\circ}\right)$ & Volume $\left(\AA^{3}\right)$ & Reference \\
\hline 2 & $\mathrm{PbFe}_{2}^{3+}\left(\mathrm{AsO}_{4}\right)_{2}(\mathrm{OH})_{2}$ carminite & $16.604(2)$ & $7.586(1)$ & $12.274(2)$ & 90 & 1546.01 & Olmi and Sabelli (1995) \\
\hline 3 & $\mathrm{PbFe}_{2}^{3+}\left(\mathrm{AsO}_{4}\right)_{2}(\mathrm{OH})_{2}$ carminite & $16.617(4)$ & $7.585(2)$ & $12.272(2)$ & 90 & 1546.76 & Olmi and Sabelli (1995) \\
\hline 5 & $\mathrm{PbFe}_{2}^{3+}\left(\mathrm{AsO}_{4}\right)_{2}(\mathrm{OH})_{2}$ carminite & $16.591(2)$ & $7.580(1)$ & $12.285(1)$ & 90 & 1544.96 & Kharisun et al. (1996) \\
\hline 6 & $\mathrm{CaFe}_{2}^{3+}\left(\mathrm{AsO}_{4}\right)_{2}(\mathrm{OH})_{2}$ sewardite & $16.461(2)$ & $7.434(1)$ & $12.131(2)$ & 90 & 1484.48 & Roberts et al. (2002) \\
\hline 7 & $\begin{array}{l}\left(\mathrm{Pb}_{1.06} \mathrm{Ca}_{0.06}\right)\left(\mathrm{Fe}_{1.71} \mathrm{Zn}_{0.05} \mathrm{Al}_{0.04} \mathrm{Cu}_{0.01}\right) \\
\quad\left(\mathrm{P}_{1.32} \mathrm{As}_{0.61} \mathrm{~V}_{0.05} \mathrm{~S}_{0.02}\right) \mathrm{O}_{8}\left[(\mathrm{OH})_{1.64}\left(\mathrm{H}_{2} \mathrm{O}\right)_{0.36}\right] \\
\text { crimsonite }\end{array}$ & $16.2535(13)$ & $7.4724(4)$ & $12.1533(9)$ & 90 & 1476.04(17) & Kampf et al. (2016) \\
\hline 8 & $\mathrm{Sr}_{1.4} \mathrm{Fe}_{1.6}\left(\mathrm{AsO}_{4}\right)_{2}(\mathrm{OH})_{1.6}$ synthetic compound & $9.072(2)$ & $12.227(2)$ & $7.546(2)$ & $114.575(6)$ & $761.2(2)$ & This work (II) \\
\hline 9 & $\begin{array}{l}\mathrm{Pb}_{2}\left(\mathrm{Fe}_{0.65} \mathrm{Zn}_{0.35}\right)\left(\mathrm{AsO}_{4}\right)_{2}\left[(\mathrm{OH})_{0.65}\left(\mathrm{H}_{2} \mathrm{O}\right)_{0.35}\right] \\
\quad \text { arsenbrackebuschite }\end{array}$ & 7.763(1) & $6.046(1)$ & $9.022(1)$ & $112.5(1)$ & 391.2(1) & $\begin{array}{l}\text { Hofmeister and } \\
\text { Tillmanns (1978) }\end{array}$ \\
\hline 10 & $\mathrm{Ba}_{2} \mathrm{Fe}^{3+}\left(\mathrm{AsO}_{4}\right)_{2}(\mathrm{OH})$, canosioite & $7.8642(4)$ & $6.1083(3)$ & $9.1670(5)$ & $112.874(6)$ & $405.73(4)$ & Cámara et al. (2017) \\
\hline 11 & $\mathrm{~Pb}_{2}(\mathrm{Mn}, \mathrm{Fe})\left(\mathrm{VO}_{4}\right)_{2}(\mathrm{OH})$ brackebuschite, $B 2_{1} / m$ & $7.68(1)$ & $6.15(5)$ & $16.52(2)$ & 93.75 & 779.525 & Donaldson et al. (1955) \\
\hline 12 & $\mathrm{~Pb}_{2} \mathrm{Mn}^{3+}\left(\mathrm{VO}_{4}\right)_{2}(\mathrm{OH})$ brackebuschite & $7.650(1)$ & $6.135(1)$ & $8.863(1)$ & $111.76(1)$ & 386.325 & Foley et al. (1997) \\
\hline 13 & $\mathrm{~Pb}_{2} \mathrm{Mn}^{3+}\left(\mathrm{VO}_{4}\right)_{2}(\mathrm{OH})$ brackebuschite & $7.6492(1)$ & $6.1262(1)$ & $8.9241(2)$ & $112.195(1)$ & $387.202(12)$ & $\begin{array}{l}\text { Lafuente and Downs } \\
\text { (2016) }\end{array}$ \\
\hline
\end{tabular}

$\mathrm{OH}$ or $\mathrm{H}_{2} \mathrm{O}$ depends on the amount of $M^{3+}$ and $M^{2+}$ cations and the valence and quantity of the large cation $A$.

The novel-type crystal structure of III is characterised by the unique octahedral-tetrahedral-quadruple, $\left[\mathrm{Fe}\left(\mathrm{AsO}_{4}\right)\right]_{\mathrm{n}}$ infinite chains, which are composed of one central double and two peripheral single chains extended along the $a$ axis. Similar verticessharing double-sided chains of octahedra and tetrahedra has been found in galliskiite, $\mathrm{Ca}_{4} \mathrm{Al}_{2}\left(\mathrm{PO}_{4}\right)_{2} \mathrm{~F}_{8} \cdot 5 \mathrm{H}_{2} \mathrm{O}$ (Kampf et al., 2010) and some phosphates (Mills et al., 2010a, 2010b and references therein). Dissimilar quadruple chains are found in the synthetic ferric sulfate trihydrate, $\mathrm{Fe}_{2}\left(\mathrm{SO}_{4}\right)_{3} \cdot 3 \mathrm{H}_{2} \mathrm{O}$ (Xu and Parise, 2011). Besides the exceptional occurrence of quadruple chains of $\mathrm{FeO}_{6}$ and $\mathrm{AsO}_{4}$ polyhedra, the characteristics of this structure are the novel chemical composition and the extremely high positional disorder of Sr2 atoms.

\section{Conclusion}

The results of phase formation studies in the system $\mathrm{Sr}-\mathrm{M}^{2+}-\mathrm{As}-\mathrm{O}-$ $\mathrm{H}$ increase the knowledge on $\mathrm{SrM}$-oxoarsenates $(\mathrm{V})$ and their crystal structures. All three structures have different chains as the primary building units. Compound $\mathbf{I}$ is a new strontium nickel analogue of tsumcorite $\mathrm{PbZn}_{2}\left(\mathrm{AsO}_{4}\right)_{2} \cdot 2 \mathrm{H}_{2} \mathrm{O}$ (monoclinic, s.g. $\mathrm{C} 2 / \mathrm{m}$ ) having a structure which is built up of infinite linear edge-sharing $\mathrm{NiO}_{4}\left(\mathrm{OH}_{2}\right)_{2}$ octahedral chains with $\mathrm{AsO}_{4}$ tetrahedra and $\mathrm{SrO}_{8}$ polyhedra linking them by sharing corners. Compound II exists as an unusual intermediate form between carminite, $\mathrm{PbFe}_{2}^{3+}\left(\mathrm{AsO}_{4}\right.$ )$^{2}(\mathrm{OH})_{2}$ and arsenbrackebuschite, $\mathrm{Pb}_{2} \mathrm{Fe}^{3+}\left(\mathrm{AsO}_{4}\right)_{2}(\mathrm{OH})$ type structures. The characteristic feature of compound II is that it hosts two type of chains: (i) octahedral vertex- and edge-sharing $\mathrm{FeO}_{4}(\mathrm{OH})_{2}$ chains like in carminite and (ii) chains similar to arsenbrackebuschite which involves $\mathrm{SrO}_{11}$ coordination polyhedra, known as Edshammar polyhedra, that can be described as a combination of a trigonal bipyramid and trigonal prism centred by the same $\mathrm{Sr}$ atom surrounded by 11 oxygen atoms.

The $M \Phi_{6}$ octahedra $\left(\Phi=\mathrm{O}, \mathrm{OH}\right.$ or $\left.\mathrm{OH}_{2}\right)$ in I like in tsumcorite and arsenbrackebuschite is all edge sharing, in contrast to the alternating edge and vertices sharing in carminite and II. In carminite and II structures two $M \Phi_{6}$ octahedra share edges to form a $M_{2} \Phi_{10}$ dimer and the $M_{2} \Phi_{10}$ dimers share corners to form an $M_{2} \Phi_{8}$ chain that is decorated by $\mathrm{XO}_{4}$ tetrahedra. These parallel chains are linked to form a framework by sharing octahedron and tetrahedron vertices. Contrary to this, the arsenbrackebuschite and tsumcorite $M \Phi_{6}$ octahedra share one set of trans edges with adjacent octahedra to form a $M \Phi_{4}$ chain. Adjacent octahedra are bridged by $\mathrm{XO}_{4}$ tetrahedra to form a decorated chain. The parallel chains in tsumcorite are further linked in the $M_{2}\left(X_{4}\right)_{2} \Phi_{2}$ sheets similar to those in natrochalcite (nominally $\left.\mathrm{NaCu}_{2}\left(\mathrm{SO}_{4}\right)_{2}(\mathrm{OH}) \cdot 2 \mathrm{H}_{2} \mathrm{O}\right)$. No such linkage occurs in arsenbrackebuschite where the $M \Phi_{6}$ octahedra occupy only half of the octahedral sites, because every second octahedral chain is omitted and replaced by chains of 11-coordinated $\mathrm{Pb}$. Similar substitutions were found in II i.e. nearly $20 \%$ of the octahedra chains are replaced by $\mathrm{SrO}_{11}$ polyhedra chains. The 8- and 11-coordinated $\mathrm{Sr}$ atoms in II adopt an almost identical polyhedral environment, such as in the synthetic compound $\mathrm{Sr}_{2} \mathrm{~V}\left(\mathrm{VO}_{4}\right)_{2}(\mathrm{OH})$ with a brackebuschite-type structure (Sanjeewa et al., 2015).

Compound III exhibits a new type of structure having interesting novel quadruple chains which are composed of $\mathrm{FeO}_{6}$ octahedra alternating with $\mathrm{AsO}_{4}$ tetrahedra sharing corners. In the structure of III the quadruple chains are connected with $\mathrm{AsO}_{4}$ tetrahedra in a 3D open framework with the channels occupied by $\mathrm{Sr}$ atoms.

The chains in I have the same topology as the chains in tsumcorite and the chains in II have the topology as the chains in carminite and brackebuschite. Quadruple chains of a topology different to that of III were found in the synthetic compound $\mathrm{Fe}_{2}\left(\mathrm{SO}_{4}\right)_{3} \cdot 3 \mathrm{H}_{2} \mathrm{O}(\mathrm{Xu}$ and Parise, 2011).

The further interesting feature of these structures is variable coordination geometry of $\mathrm{Sr}^{2+}$ cations combined with the substitutional (in II) and positional (in II and III) disorder. The strontium coordination geometries include near-prismatic $\mathrm{SrO}_{8}$ coordination polyhedra in I and II, the chains of Edshammar $\mathrm{SrO}_{11}$ coordination polyhedra in II and mutually isolated $\mathrm{Sr}_{2} \mathrm{O}_{16}$ dimers in III. 
We have shown that the compounds from the $\mathrm{M} 1-\mathrm{M} 2-\mathrm{As}-\mathrm{O}-$ $\mathrm{H}$ system $\left(\mathrm{M} 1=\mathrm{Ca}^{2+}, \mathrm{Sr}^{2+}\right.$ and $\mathrm{Ba}^{2+} ; \mathrm{M} 2=\mathrm{Mn}^{2+, 3+}, \mathrm{Fe}^{2+, 3+}, \mathrm{Co}^{2+}$, $\mathrm{Ni}^{2+}, \mathrm{Cu}^{2+}$ and $\mathrm{Zn}$ ) are not fully structurally and chemically defined. However, they could play an important role as the arsenic scavengers in arsenic-extreme environments, such as sulfidic mining wastes and tailings. Two of three investigated phases crystallises in a novel structure type and thus add details to the crystal chemistry of oxoarsenate $(\mathrm{V})$ compounds.

Supplementary material. To view supplementary material for this article, please visit https://doi.org/10.1180/mgm.2021.41

Acknowledgements. This work was supported financially by the Austrian Science Foundation (FWF) (Grant V203-N19) and by the Ministry of Education, Science and Technological Development of the Republic of Serbia (grant No. III45007). The article was improved by constructive reviews by Peter Leverett and one anonymous reviewer.

\section{References}

Assani A., Saadi M., Zriouil M. and El Ammari L. (2010) $\mathrm{Ni}_{2} \mathrm{Sr}_{2}\left(\mathrm{PO}_{4}\right)_{2} \cdot 2 \mathrm{H}_{2} \mathrm{O}$. Acta Crystallographica, E66, i86-i87.

Brese N.E. and O'Keeffe M. (1991) Bond-valence parameters for solids. Acta Crystallographica, B47, 192-197.

Brown I.D. and Altermatt D. (1985) Bond-valence parameters obtained from a systematic analysis of the Inorganic Crystal Structure Database. Acta Crystallographica, B41, 244-247.

Brugger J., Meisser N., Schenk K., Berlepsch P., Bonin M., Armbruster T., Nyfeler D. and Schmidt S. (2000) Description and crystal structure of cabalzarite $\mathrm{Ca}(\mathrm{Mg}, \mathrm{Al}, \mathrm{Fe})_{2}\left(\mathrm{AsO}_{4}\right)_{2}\left(\mathrm{H}_{2} \mathrm{O}, \mathrm{OH}\right)_{2}$, a new mineral of the tsumcorite group. American Mineralogist, 85, 1307-1314.

Brugger J., Armbruster T., Criddle A.J., Berlepsch P., Graeser S. and Reeves S. (2001) Description, crystal structure, and paragenesis of krettnichite, $\mathrm{PbMn}_{2}\left(\mathrm{VO}_{4}\right)_{2}(\mathrm{OH})_{2}$, the $\mathrm{Mn}^{3+}$ analogue of mounanaite. European Journal of Mineralogy, 13, 145-158.

Brugger J., Krivovichev S.V., Kolitsch U., Meisser N., Andrut M., Ansermet S. and Burns P.C. (2002) Description and crystal structure of manganlotharmeyerite, $\mathrm{Ca}(\mathrm{Mn}, \square, \mathrm{Mg})_{2}\left\{\mathrm{AsO}_{4},\left[\mathrm{AsO}_{2}(\mathrm{OH})_{2}\right]\right\}_{2}\left(\mathrm{OH}, \mathrm{H}_{2} \mathrm{O}\right)_{2}$, from the Starlera Mn-deposit, Swiss Alps, and a redefinition of lotharmeyerite Locality: Starlera Mn-deposit, Swiss Alps. The Canadian Mineralogist, 40, 1597-1608.

Cámara F., Bittarello E., Ciriotti M.E., Nestola F., Radica F., Massimi F., Balestra C. and Bracco R. (2017) As-bearing new mineral species from Valletta mine, Maira Valley, Piedmont, Italy: III. Canosioite, $\mathrm{Ba}_{2} \mathrm{Fe}^{3+}\left(\mathrm{AsO}_{4}\right)_{2}(\mathrm{OH})$, description and crystal structure, Mineralogical Magazine, 81, 305-317.

De Pedro I., Rojo J.M., Pizarro J.L., Rodriguez Fernandez J., Arriortua M.I. and Rojo T. (2011): Magnetostructural correlations in the antiferromagnetic $\mathrm{Co}_{2}$ ${ }_{-\mathrm{x}} \mathrm{Cu}_{\mathrm{x}}(\mathrm{OH}) \mathrm{AsO}_{4}$ ( $x=0$ and 0.3 ) phases. Journal of Solid State Chemistry, 184, 2075-2082

Donaldson D.M. and Barnes W.H. (1955) The structures of the minerals of the descloizite and adelite groups: III- brackebuschite. American Mineralogist, 40, 597-613.

Đorđević T. and Karanović Lj. (2018): Three new Sr-bearing arsenates, hydrothermally synthesized in the system $\mathrm{SrO}-\mathrm{MO}-\mathrm{As}_{2} \mathrm{O}_{5}-\mathrm{H}_{2} \mathrm{O}\left(M^{2+}=\mathrm{Mg}, \mathrm{Cu}\right.$, $\mathrm{Zn})$. European Journal of Mineralogy, 29, 73-89.

Đorđević T., Karanović Lj. and Jagličić Z. (2018) A new copper(II) arsenate, $\mathrm{Na}_{2} \mathrm{Cu}_{3}\left(\mathrm{AsO}_{3} \mathrm{OH}\right)_{4} \cdot 4 \mathrm{H}_{2} \mathrm{O}$ containing discrete $\left[\mathrm{Cu}_{3} \mathrm{O}_{12}\right]^{18-}$ units: Synthesis, crystal structure and magnetic properties. Journal of Solid State Chemistry, 265, 55-63.

Dowty E. (2000) ATOMS for Windows. Shape software, 521, Hidden Valley Kingsport, Tennessee, USA.

Drahota P. and Filippi M. (2009) Secondary arsenic minerals in the environment: a review. Environment International, 35, 1243-1255.

Edshammar L.E. (1969) X-ray Studies in Binary Alloys of Aluminium with Platinum Metals. Thesis, University of Stockholm, Sweden.

Effenberger H., Krause W., Bernhardt H.J. and Martin M. (2000) On the symmetry of tsumcorite group minerals based on the new species rappoldite and zincgartrellite, Mineralogical Magazine, 64, 1109-1126.
Elliott P. and Pring A. (2015) Yancowinnaite, a new mineral from the Kintore Opencut, Broken Hill, New South Wales. Australian Journal of Mineralogy, $17,73-76$.

Farrugia L.J. (2012) WinGX and ORTEP for Windows: an update. Journal of Applied Crystallography, 45, 849-854.

Finney J.J. (1963) The crystal structure of carminite, American Mineralogist, 48, $1-13$.

Foley J.A., Hughes J.M. and Lange D. (1997) The atomic arrangement of brackebuschite, redefined as $\mathrm{Pb}_{2}(\mathrm{Mn}, \mathrm{Fe})\left(\mathrm{VO}_{4}\right)_{2}(\mathrm{OH})$, and comments on Mn octahedral. The Canadian Mineralogist, 35, 1027-1033.

Gagné O.C. and Hawthorne F.C. (2016) Bond lengths for ions bonded to oxygen. Acta Crystallography. B72, 602-625.

Gonzalez del Tanago J., La Iglesia A., Rius J. and Fernandez Santin S. (2003) Calderonite, a new lead-iron-vanadate of the brackebuschite group. American Mineralogist, 88, 1703-1708.

Hawthorne F.C. (2014) The structure hierarchy hypothesis. Mineralogical Magazine, 78, 957-1027.

Hawthorne F.C., Krivovichev S.V. and Burns P.C. (2000) The crystal chemistry of sulfate minerals. Pp. 1-101 in: Sulfate Minerals - Crystallography, Geochemistry and Environmental Significance (C.N. Alpers, J.L. Jambor and D.K. Nordstrom, editors). Reviews in Mineralogy and Geochemistry, 40. Mineralogical Society of America and the Geochemical Society, Chantilly, Virginia, USA.

Hofmeister W. and Tillmanns E. (1978) Strukturelle Untersuchungen an Arsenbrackebuschit. Tschermaks mineralogische und petrographische Mitteilungen, 25, 153-163.

Kampf A.R., Colombo F., Simmons W.B., Falster A.U. and Nizamoff J.W. (2010) Galliskiite, $\mathrm{Ca}_{4} \mathrm{Al}_{2}\left(\mathrm{PO}_{4}\right)_{2} \mathrm{~F}_{8} \cdot 5 \mathrm{H}_{2} \mathrm{O}$, a new mineral from the Gigante granitic pegmatite, Cordoba province, Argentina. American Mineralogist, 95, 392-396.

Kampf A.R., Adams P.M., Mills S.J. and Nash B.P. (2016) Crimsonite, $\mathrm{Pb}^{2+} \mathrm{Fe}_{2}^{3+}$ $\left(\mathrm{PO}_{4}\right)_{2}(\mathrm{OH})_{2}$, the phosphate analogue of carminite from the Silver Coin mine, Valmy, Nevada, USA. Mineralogical Magazine, 80, 925-935.

Kharisun, Taylor M.R., Bevan D.J.M. and Pring A. (1996) The crystal structure of carminite: refinement and bond valence calculations. Mineralogical Magazine, 60, 805-811.

Kharisun, Taylor M.R., Bevan D.J.M., Rae A.D. and Pring A. (1997) The crystal structure of mawbyite, $\mathrm{PbFe}_{2}\left(\mathrm{AsO}_{4}\right)_{2}(\mathrm{OH})_{2}$. Mineralogical Magazine, 61, 685-691.

Krause W., Belendorff K., Bernhardt H.-J., McCammon C., Effenberger H. and Mikenda W. (1998) Crystal chemistry of the tsumcorite-group minerals. New data on ferrilotharmeyerite, tsumcorite, thometzekite, mounanaite, helmutwinklerite, and a redefinition of gartrellite. European Journal of Mineralogy, 10, 179-206.

Krause W., Bernhardt H. J., Effenberger H. and Martin M. (2001a) Cobalttsumcorite and nickellotharmeyerite, two new minerals from Schneeberg, Germany: description and crystal structure. Neues Jahrbuch für Mineralogie, Monatshefte, 2001, 558-576.

Krause W., Blass G., Bernhardt H. J. and Effenberger H. (2001b) Lukrahnite, $\mathrm{CaCuFe}^{3+}\left(\mathrm{AsO}_{4}\right)_{2}\left[\left(\mathrm{H}_{2} \mathrm{O}\right)(\mathrm{OH})\right]$, the calcium analogue of gartrellite, Neues Jahrbuch für Mineralogie, Monatshefte, 11, 481-492.

Krause W., Bernhardt H. J., Effenberger H. and Witzke T. (2002) Schneebergite and nickelschneebergite from Schneeberg, Saxony, Germany: the first Bi-bearing members of the tsumcorite group. European Journal of Mineralogy, 14, 115-126.

Krickl R. and Wildner M. (2007) Crystal chemistry of synthetic Co- and $\mathrm{Ni}$-analogues of natrochalcite - the shortest known hydrogen bonds among mineral-type compounds, Part I: Single-crystal X-ray structures. European Journal of Mineralogy, 19, 805-816.

Lafuente B. and Downs R.T. (2016) Redetermination of brackebuschite, $\mathrm{Pb}_{2} \mathrm{Mn}^{3+}\left(\mathrm{VO}_{4}\right)_{2}(\mathrm{OH})$. Acta Crystallographica, E72, 293-296.

Libowitzky E. (1999) Correlation of O-H stretching frequencies and $\mathrm{O}-\mathrm{H} \cdots \mathrm{O}$ hydrogen bond lengths in minerals. Monatshefte für Chemie, 130, 1047-1059.

Mihajlović T. and Effenberger H. (2004) The first proof of protonated anion tetrahedra in the tsumcorite-type compounds. Mineralogical Magazine, 68, 757-767.

Mills S.J., Birch W.D.; Kampf A.R., Christy A.G., Pluth J.J., Pring A., Raudsepp M. and Chen Y.S. (2010a) Kapundaite, $(\mathrm{Na}, \mathrm{Ca})_{2} \mathrm{Fe}_{4}^{3+}\left(\mathrm{PO}_{4}\right)_{4}(\mathrm{OH})_{3} \cdot 5 \mathrm{H}_{2} \mathrm{O}$, a new phosphate species from Toms quarry, South Australia: Description and structural relationship to melonjosephite. American Mineralogist, 95, 754-760. 
Mills S.J., Kolitsch U., Miyawaki R., Hatert F., Poirier G., Kampf A.R., Matsubara S. and Tillmanns E. (2010b) $\mathrm{Pb}_{3} \mathrm{Fe}_{2}^{3+}\left(\mathrm{PO}_{4}\right)_{4} \cdot\left(\mathrm{H}_{2} \mathrm{O}\right)$, a new octahedral-tetrahedral framework structure with double-strand chains. European Journal of Mineralogy, 22, 595-604.

Momma K. and Izumi F. (2011) VESTA 3 for three-dimensional visualization of crystal, volumetric and morphology data. Journal of Applied Crystallography, 44, 1272.

Nonius (2005-2007) COLLECT data collection software. Nonius BV, Delft, The Netherlands.

O’Day P.A. (2006) Chemistry and mineralogy of arsenic. Elements, 2, 77-83.

Olmi F. and Sabelli C. (1995) Carminite from three localities of Sardinia (Italy). Crystal structure refinements. Neues Jahrbuch für Mineralogie, Monatshefte, 1995, 553-562.

Otwinowski Z., Borek D., Majewski W. and Minor W. (2003) Multiparametric scaling of diffraction intensities. Acta Crystallographica, A59, 228-234.

Pekov I.V., Chukanov N.V., Varlamov D.A., Belakovskiy D.I., Turchkova A.G., Voudouris P., Katerinopoulos A. and Magganas A. (2016) Nickeltsumcorite, $\mathrm{Pb}\left(\mathrm{Ni}, \mathrm{Fe}^{3+}\right)_{2}\left(\mathrm{AsO}_{4}\right)_{2}\left(\mathrm{H}_{2} \mathrm{O}, \mathrm{OH}\right)_{2}$, a new tsumcorite-group mineral from Lavrion, Greece. Mineralogical Magazine, 80, 337-346.

Pring A., McBriar E.M. and Birch W.D. (1989 ) Mawbyite a new arsenate of lead and iron related to tsumcorite and carminite from Broken Hill New South Wales. American Mineralogist, 74, 1379-1381.

Roberts A.C., Cooper M.A., Hawthorne F.C., Criddle A.J. and Stirling J.A.R. (2002) Sewardite, $\mathrm{CaFe}^{3+2}\left(\mathrm{AsO}_{4}\right)_{2}(\mathrm{OH})_{2}$, the Ca-analogue of carminite, from Tsumeb, Namibia: description and crystal structure. The Canadian Mineralogist, 40, 1191-1198.

Sanjeewa L.D., McGuire M.A., Garlea V.O., Hu L., Chumanov G., McMillen C.D. and Kolis J.W. (2015) Hydrothermal synthesis and characterization of novel brackebuschite-type transition metal vanadates: $\mathrm{Ba}_{2} M$ $\left(\mathrm{VO}_{4}\right)_{2}(\mathrm{OH}), M=\mathrm{V}^{3+}, \mathrm{Mn}^{3+}$, and $\mathrm{Fe}^{3+}$, with interesting Jahn-Teller and spin-liquid behaviour. Inorganic Chemistry, 54, 7014-7020.

Shannon R.D. (1976) Revised effective ionic radii and systematic studies of interatomic distances in halides and chalcogenides. Acta Crystallographica, A32, 751-767.

Sheldrick G.M. (2015a) SHELXT - Integrated space-group and crystal structure determination. Acta Crystallographica, A71, 3-8.

Sheldrick G.M. (2015b) Crystal structure refinement with SHELXL. Acta Crystallographica, C71, 3-8.

Stoe (2013) X-AREA and X-RED32. Stoe \& Cie, Darmstadt, Germany.

Tillmanns E. and Gebert W. (1973) The crystal structure of tsumcorite, a new mineral from the Tsumeb Mine, S.W. Africa. Acta Crystallographica, B29, 2789-2794.

Wills A.S. (2010) VaList - Bond Valence Software for Windows. http://www. CCP14.ac.uk

$\mathrm{Xu}$ W.Q. and Parise J.B. (2011) Synthetic ferric sulfate trihydrate Fe2 $\left(\mathrm{SO}_{4}\right)_{3} \cdot 3 \mathrm{H}_{2} \mathrm{O}$, a new ferric sulfate salt. Acta Crystallographica, C67, i30-i32

Yang Y.W., Evans S.H., Downs R.T. and Yang H. (2012) Lotharmeyerite, Ca $(\mathrm{Zn}, \mathrm{Mn})_{2}\left(\mathrm{AsO}_{4}\right)_{2}\left(\mathrm{H}_{2} \mathrm{O}, \mathrm{OH}\right)_{2}$, Acta Crystallographica, E68, i9-i10. 